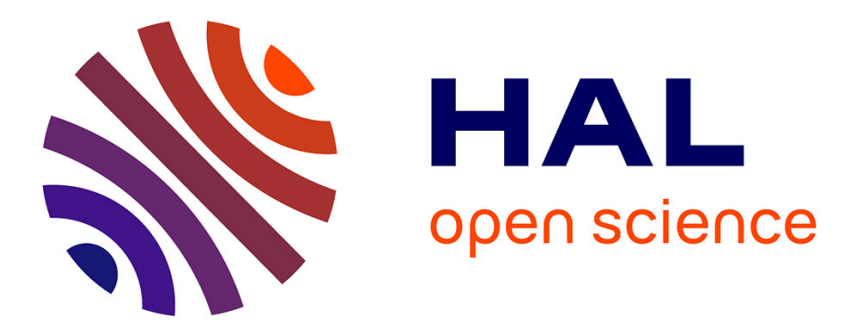

\title{
Establishing Primary Cultures of Trunk Neural Crest Cells
}

\author{
Jean-Loup Duband, Nioosha Nekooie - Marnany, Sylvie Dufour
}

\section{To cite this version:}

Jean-Loup Duband, Nioosha Nekooie - Marnany, Sylvie Dufour. Establishing Primary Cultures of Trunk Neural Crest Cells. Current Protocols in Cell Biology, 2020, 88 (1), pp.e109. 10.1002/cpcb.109 . inserm-02927499

\section{HAL Id: inserm-02927499 https://www.hal.inserm.fr/inserm-02927499}

Submitted on 5 Aug 2021

HAL is a multi-disciplinary open access archive for the deposit and dissemination of scientific research documents, whether they are published or not. The documents may come from teaching and research institutions in France or abroad, or from public or private research centers.
L'archive ouverte pluridisciplinaire HAL, est destinée au dépôt et à la diffusion de documents scientifiques de niveau recherche, publiés ou non, émanant des établissements d'enseignement et de recherche français ou étrangers, des laboratoires publics ou privés. 
"This is the pre-peer reviewed version of the following article: Duband JL, Nekooi-Marnany N, and Dufour S. Establishing primary cultures of trunk neural crest cells. 2020 Curr Protoc Cell Biol. 2020 Sep;88(1):e109., which has been published in final form at [doi: 10.1002/cpcb.109]. This article may be used for non-commercial purposes in accordance with Wiley Terms and Conditions for Use of Self-Archived Versions."

\title{
Establishing primary cultures of trunk neural crest cells
}

\author{
Jean-Loup Duband*, Nioosha Nekooie-Marnany, and Sylvie Dufour
}

Institut Mondor de Recherches Biomédicales, INSERM U955, Université Paris-Est Créteil, 94000 Créteil, France

* Author for correspondence. email: jean-loup.duband@inserm.fr

Running title: Avian trunk neural crest cell culture

Keywords: neural crest, avian embryo, cell culture, cell migration, cell lineage, stem cells, Phenotyping

\begin{abstract}
Neural cest cells constitute a unique population of progenitor cells with extensive stem cell capacities, able to navigate throughout various environments in the embryo, and source of multiple cell types, including neurons, glia, melanocytes, smooth muscles, endocrine cells, cardiac cells, and also skeletal and supportive tissues in the head. Neural crest cells are not restricted to the embryo but they persist as well in adult tissues where they provide a reservoir of stem cells with great therapeutic promises. Many fundamental questions in cell, developmental and stem cell biology can be addressed using this system. During the last decades there has been an increased availability of elaborated techniques, animal models and molecular tools to tackle neural crest cell development. However, these approaches are often very challenging and difficult to establish and they are not adapted for rapid functional investigations of mechanisms driving cell migration and differentiation. In addition, they are not adequate for collecting pure populations of neural crest cells usable in large scale analyses and for stem cell studies. Transferring and adapting the neural crest system in tissue culture may then represent an attractive alternative opening numerous prospects.

Here we describe a simple method for establishing primary cultures of neural crest cells derived from trunk neural tubes using the avian embryo as a source of cells. This protocol is suited for producing pure populations of neural crest cells that can be processed for cytological, cellular and functional approaches aimed at characterizing their phenotype, behavior and potential.

Because neural crest cells constitute a population of stem cells of the vertebrate embryo able to colonize numerous tissues and provide a large array of cell types (Le Douarin and Kalcheim, 1999; Trainor, 2013), they represent an attractive model for cell and developmental biologists to investigate how the basic cellular processes, such as proliferation, survival, adhesion, migration, and differentiation, are coordinated in time and space to generate highly-organized and specialized cellular assemblies in the organism. In brief, the neural crest develops all along the embryonic anteroposterior (or rostrocaudal) axis, at the junction between the ectoderm, i.e. the future epidermis, and the neural plate, i.e. the primordium of the central nervous system.
\end{abstract}


After specification early during development, progenitors of the neural crest situated initially at the periphery of the blastoderm become gradually positioned at the apex of the neural tube along the embryonic midline. Later on, by a mechanism related to epithelium-mesenchyme transition, they delaminate from the neural tube and disperse through defined, spatiallyrestricted pathways to colonize many different territories throughout the embryo. Ultimately, they differentiate into a large collection of cell types, ranging from neurons, glia, or melanocytes, to endocrine and cardiac cells, as well as most skeletal and supportive tissues of the head. Interestingly, neural crest cells provide large contingents of stem cells in adult tissues, such as in the nervous system, heart, skin, gut, teeth and bones (Liu and Cheung, 2016), and a recent and growing literature highlighted that a population of neural crest cells persists in adulthood, being able to give rise to derivatives in several body sites just as their embryonic counterpart (Furlan and Adameyko, 2018). As a consequence, any shortcomings in neural crest cell development may lead to dramatic congenital craniofacial, cardiac or enteric disorders and may be as well associated with the occurrence of various pathologies later after birth and in the adult, notably pediatric cancers like neuroblastoma and neurofibromatosis and melanoma. Therefore, neural crest cells represent a challenging and promising cellular population with a formidable potential in tissue repair and replacement therapies both during embryogenesis and in the adult.

Neural crest cells are partitioned spatially into distinct populations (cranial, cardiac, vagal, trunk and sacral) differing by their cellular properties and fate all along the rostrocaudal axis of the embryo, and this is instrumental for elucidating how intrinsic and extrinsic influences integrate over time to direct their spatially-appropriate differentiation. Strikingly, unlike many other embryonic populations, neural crest cells execute their main developmental steps (specification, dispersion, expansion and differentiation) sequentially and in separate locations of the embryo (Duband et al., 2015), making this system highly suitable for analyzing each step individually and for understanding how they are temporally coordinated.

The last decades witnessed the emergence of a variety of elaborated techniques, animal models and molecular tools to investigate neural crest cell development in vivo (Betancur et al., 2010; Baggiolini et al., 2015; Hockman et al., 2019; Li et al., 2019; Soldatov et al., 2019; Williams et al., 2019). These studies are at the origin of considerable progress in our understanding of this cell population. However, these approaches are often very challenging and out of reach for most cell biology laboratories, because many of them require a combination of different specific skills in developmental biology, they are difficult and long to establish, and may be costly. In addition, they either cannot be easily tailored to current cell biology techniques, notably highresolution imaging, or would require very sophisticated devices. Hence, they do not allow rapid and easy analyses to address specific questions on defined cellular events. Therefore, transferring the neural crest system in culture may represent a very attractive alternative opening numerous perspectives.

Unlike many other embryonic cells, neural crest cells cannot be conveniently collected for culture in large quantities and free of contaminants directly from the embryo. Indeed, during migration, they are scattered among the neighboring embryonic tissues and they cannot be easily discriminated from other cells for extirpation. In addition, often soon after initiation of migration, neural crest cells engage precociously into differentiation and may then lose some of their initial properties. Conversely, at early developmental stages, neural crest progenitors fail to develop further in culture and to acquire all neural crest cell features, in particular their migration capacity and differentiation potential. Nevertheless, neural crest cells can be successfully cultured in vitro if they are derived from the neural tube precisely at the time when they are upon to initiate migration. At this stage, the neural tube is a well delineated tissue that can be easily excised out of the embryo and, upon explantation in culture, it releases swiftly its neural crest cell contingent which then adhere to the dish, migrate and proliferate, forming 
ultimately after 24 hours a large cell outgrowth surrounding the neural tube. Moreover, neural crest cells can be cultured for relatively-prolonged time periods, up to one or two weeks, and under appropriate conditions, they can undergo differentiation into various cell types (Dupin and Coelho-Aguiar, 2013; Dupin et al., 2018).

Thus, using this method, each of the different steps that accompany neural crest cell development as well as their main features (rate of cell proliferation, cellular interactions within the population, and timing and kinetics of the cellular events) can be recapitulated in vitro and analyzed individually. Practically, this method relies on the fact that neural crest ontogeny proceeds along a rostrocaudal gradient. During the third day of embryonic development, only the portion of the neural tube situated along the last-formed somites is able to produce immediately large quantities of migrating neural crest cells when explanted in culture, and neither more anterior nor more posterior neural tubes can produce significant populations of cells with a complete neural crest phenotype (Duband et al., 2009).

Neural crest cell development has been explored in a variety of vertebrate species ranging from lower vertebrates (lamprey), fish and frogs (zebrafish and Xenopus) to amniotes (chick, quail, mouse, rat and now human). Although cultures of neural crest cells can be theoretically generated from most of these species, the use of the avian model is recommended for beginners for a variety of reasons. First, it can be easily and rapidly set up with no special reagents and skills. A little practice is generally sufficient. In addition, it is affordable and may even be used for experiments requiring relatively-large quantities of biological material because embryos can be collected in larger amounts than with mouse and synchronized to the same developmental stage. Finally, most neural crest cell derivatives can be successfully obtained in culture with avian embryos and the evolutionary proximity between birds and mammals make it convenient for the use of all sorts of molecular tools for functional studies. Here we describe the basic method to isolate neural tube explants from trunk segments of quail embryos and produce pure populations of neural crest cells, and we present tools necessary for their phenotypic characterization.

NOTE: It should be stressed that the method described below requires neither specific technical skill nor a long practice and expertise in experimental developmental biology. Calm, meticulousness, and patience generally help to overcome all the issues, and there are no particularly-difficult and stressful steps that have to be conducted in a very limited timing. Train first with a few eggs, e.g. a dozen, to get practice, to appreciate the difficulties and pitfalls of the method and to know your limits, and follow the basic rules and recommendations that are explained below. A few days of training are generally sufficient to undertake a full-scale experiment in a completely-autonomous fashion. Failing a few eggs at the beginning is no big deal (they are cheap!) and should not discourage you to persevere. The only important recommendation concerns the tools used for dissection as they are key for your success. Don't hesitate to customize them to your hand (particularly left vs. right) and avoid sharing them with others.

NOTE: There is no specific requirement for primary cultures of avian embryonic tissues (they are grown essentially as mammalian cells in standard culture media, at $37^{\circ} \mathrm{C}$ and under a humidified $\mathrm{CO}_{2}$ atmosphere), but it is recommended to use proper aseptic techniques and appropriate biosafety practices to protect the experimenter and avoid contaminations of the culture. In addition, all solutions and equipment, such as microsurgery tools and dishware, coming into contact with tissues and cells must be sterile. However, because most neural crest cultures are usually not maintained for long, it is not necessary to work in a dedicated culture room and under a sterile tissue culture hood. A clean bench in a quiet lab room with minimal passage generally suffices. 


\section{PRIMARY CULTURES OF AVIAN TRUNK NEURAL CREST CELLS}

\section{Materials}

Biological samples:

Fertilized quail (Coturnix coturnix japonica) eggs from local commercial source. If quail eggs are not available, hens (Gallus gallus, White or Brown Leghorn strains) eggs can be used instead although the quality of the cultures (number and viability of neural crest cells) obtained from them is generally lower than with quail. Also keep in mind that melanocytes issued from White Leghorn chick embryo neural crest cells are not pigmented.

Reagents:

Classical phosphate-buffered saline (PBS) without $\mathrm{Ca}_{2+}$ and $\mathrm{Mg}_{2+}$. PBS can be prepared from sterile 10x stock solutions available from numerous suppliers (e.g. Sigma, cat. no. P5493). Dulbecco's PBS (i.e. phosphate buffer supplemented with glucose, sodium pyruvate and antibiotics) is an option but is not formally required. Fibronectin from bovine plasma (e.g. Sigma, cat. no. F1141). Fibronectin is generally available as a $1 \mathrm{mg} / \mathrm{ml}$ stock solution. Caution, as recommended by the manufacturer, do not store fibronectin at $-20^{\circ} \mathrm{C}$ but at $4^{\circ} \mathrm{C}$ as it is inactivated when frozen. Fibronectin in stock solution is quite stable at $4^{\circ} \mathrm{C}$ and can be stored for up to 12 months at least. Dispase II in Hanks' balanced salt solution (e.g. Stemcell Technologies, cat. no. 07913). Dispase is available as a $5 \mathrm{U} / \mathrm{ml}$ stock solution and should be aliquoted and stored at $-20^{\circ} \mathrm{C}$. Dulbecco's modified Eagle's medium (DMEM) with low glucose $(1 \mathrm{~g} / \mathrm{l})$ and sodium pyruvate $(1 \mathrm{mM})$ and supplemented with glutamine $(2 \mathrm{mM})$ and penicillin and streptomycin (each at 100 units/ml). Fetal calf serum (FCS) previously heat inactivated at $56^{\circ} \mathrm{C}$ during 30 minutes.

Equipment:

$37^{\circ} \mathrm{C}$ incubator for the eggs.

No need to use specialized egg incubators for poultry breeding with oscillating plates and controlled humidified atmosphere as eggs are incubated for less than 3 days. A basic incubator, e.g. for microbiology, generally suffices. However, the use of incubators equipped with timers is recommended to set the timing of incubation at will.

Stereomicroscope for dissection with a zoom range of about $0.8-5 \mathrm{x}$ (corresponding often to a 8-50 fold magnification) and semi-rigid swan-neck fiber optic illumination. Use only fiber optic epi-illumination and stereomicroscopes with thin stands, not diascopic stands as they are too high and not comfortable for prolonged dissections. Also be careful that the working distance between the objective and the stand is not too short for good access to the samples and easy manipulation.

Tissue culture humidified 5\%-CO $\mathrm{CO}_{2}$ incubator. Inverted microscope with $10 \mathrm{x}$ and $20 \mathrm{x}$ phase contrast objectives and equipped with a camera connected to a computer for analyses. Ideally, a heated chamber adapted to the microscope will help maintaining the cultures under optimal conditions while observing and is also required for videomicroscopy.

Miscellaneous material and equipment:

Specific glassware (Fig. 1A): widened bowl of about 15-cm diameter, glass Petri dish of about 7-cm diameter containing a layer of silicone rubber which can be casted from commerciallyavailable liquid silicone colored in black and solidified with a catalyzer. The elastic properties of this material make it extremely convenient to pin embryos down for trimming of tissues explants, and its opacity allows to visualize the detailed structure of the animal. In addition, it can be sterilized and reused many times.

Microsurgery tools (Fig. 1B): curved scissors with sharp ends, a Moria perforated spoon, a pair of straight forceps with thin tips $(0.1 \mathrm{~mm})$ (e.g. Drumont no. 4$)$, straight scissors with sharp ends, a pair of pin holders with screw, rigid stainless steel insect pins (rod diameter of 0.25-0.3 $\mathrm{mm}$ ), stainless steel minutien pins (rod diameter of 0.1-0.2 mm), a scalpel with disposable no. 
15 blade, and Arkansas stone for tool sharpening. These tools can be purchased from local suppliers (see e.g. Fine Science Tools in US or Euronexia in Europe for reference). Tungsten minutien pins are an interesting option because of their hardness and stiffness but it should be warned that they are not easy to sharpen.

Plastic culture dishes and plates of various sizes.

Neural crest cells can be cultured equally well on any kind of support (cell culture-treated or non-treated plastic, glass), provided it is coated with appropriate extracelllular matrix proteins, routinely fibronectin. The choice of the dishes depends primarily on the final goal of the culture (see Support Protocol below). For basic cultures, use preferably $35-\mathrm{mm}$ or $60-\mathrm{mm}$ dishes or 4to 24-well plates. We do not recommend 96-well culture dishes, because the wells are too deep and their edges are too steep for allowing an easy handling of the neural tube explant inside of the well.

Culture wells: Various sorts of culture wells are available from different suppliers. Cloning cylinders of 6-10-mm diameters in borosilicate (Bellco, cat. no. 2090-00808) or in stiff polystyrene (Belart, cat. no. H37847-0000) are a good option as they can be easily manipulated, sterilized and reused. Ibidi's silicone culture-inserts with 2, 3 or 4 wells (cat. no. 80209, 80309, 80409) represent an appropriate alternative because they are specifically designed for migration assays. Another cheap and easy solution is to use custom-made culture wells from Falcon 3912 MicroTest III flexible 96-well assay plate from Becton Dickinson (see below). In order to favor a rapid conditioning of their culture medium optimal for their development and survival, neural tubes and neural crest cells explanted in vitro should be maintained in limited amounts of medium (ideally 10-50 $\mu \mathrm{l}$ per neural tube explant). It is therefore preferable to place them in culture wells at least for the first day in culture, even in multiwell plates.

\section{Collecting the embryos from the eggs}

1. Preparing the eggs for incubation: Freshly-laid eggs purchased from local farms should be stored upon receipt in a fresh room at $15-20^{\circ} \mathrm{C}$ up to a week. Place the eggs in the incubator with their blunt end at the top and set the incubator timer for a 54-58 hours incubation to obtain embryos at the ideal stage for trunk neural crest cell cultures. Avoid storing eggs at $4{ }^{\circ} \mathrm{C}$ or for more than a week as it will result in a significant proportion of embryos presenting severe developmental abnormalities. Optimal temperature of incubation is at $37-38^{\circ} \mathrm{C}$, not higher as this does not speed up the embryo development, rather it causes frequent neural tube defects and may ruin your experiment. Caution, when using quail eggs, handle them with care as their shell is generally more prone to crushing than hens eggs.

2. At the completion of the incubation period, take the eggs out of the incubator. Incubated eggs can be stored at room temperature for a while up to 2-3 hours before manipulation with no advert effects and minimal developmental progression. Before starting, maintain the PBS and DMEM solutions at room temperature to minimize thermal shock.

3. Collecting the yolk from the egg (Fig. 2A): Hold the eggs with its blunt end down and remove the sharp end of the shell first by making a small slit in the shell, then by a circular movement all around it with curved dissecting scissors. Eliminate the excess of albumin and gently transfer the yolk into a bowl half-filled with PBS. Collect about 10-15 yolks at a time in the bowl. The location of the opening in the egg optimally should be in its upper third, such that the yolk is not pierced while cutting the shell and that it can pass freely through the opening while being transferred into the bowl. It is recommended to use a widened bowl with no steep edges for easy manipulation during the following step. Once it is deposited in PBS, the yolk will automatically rotate such that the embryo is presented always on its top.

4. Collecting the embryo from the yolk (Fig. 2B): The embryo can now be easily visualized with its surrounding vitelline membrane (or yolk sac). Normally at this developmental stage, the part of the vitelline membrane adjacent to the embryo proper is being vascularized with 
formation of many blood islands, delimiting a well-defined area. Cut the vitelline membrane around the vascularized area with curved scissors while holding it with forceps. Then, gently shake the embryo in the PBS to remove yolk excess and the covering, opalescent chorionic membrane, and transfer it to a PBS-containing dish using a perforated spoon. The use of perforated spoon is dispensable and may be replaced by forceps, as at this developmental stage, the vitelline membrane is resistant enough to be manipulated with them without damaging the embryo.

\section{Isolating the trunk segments}

5. Displaying the embryos for trunk segment isolation (Fig. 3A): Once all embryos are collected, transfer them into a silicone-containing glass Petri dish filled with PBS. With a forceps, spread out the vitelline membrane in the dish with the embryo dorsal side up, pin it down to the silicone layer with four insect needles, and examine the embryo carefully under the stereomicroscope at zoom $2 \mathrm{x}$ to detect any abnormalities and calculate its developmental stage. There are several ways to locate the dorsal side of the trunk region in an embryo. The simplest one is orientate the embryo such that its anterior half presents its right side to the observer as shown in Fig. 3A. Indeed, during the third day of development, most embryos (but not all of them !) have their head turned and present their right side up. Meanwhile, the trunk region has not yet rotated and still lies with its ventral side oriented to the yolk and its dorsal side up. An additional indication particularly useful for the outliers is that the embryo's head protrudes above the vitelline membrane toward the dorsal side. Lastly, another way, though less easy, is to look at the entry points of the large extraembryonic blood vessels into the embryo. The dorsal side is where they are the least discernable. Staging can be done according to the Hamburger and Hamilton $(\mathrm{HH})$ chart (Hamburger and Hamilton, 1951) or, for greater precision, by counting the total number of somite pairs, knowing that in 36-72 hours embryos, a pair of somite is formed approximately every 60-90 minutes. Note that in embryos older than 22 somites, it is not needed to count all somites but simply to count those situated caudally to the $20 \mathrm{th}-21_{\mathrm{st}}$ somite pairs. Both somites are situated on either sides of the entry point of the large extraembryonic blood vessels into the embryo. Embryos should be in the range of 18-28 somite pairs or at HH13-15. Finally, with practice, pinning down the embryos with needles can be dispensable, allowing you to reduce manipulations and save time.

6. Dissecting the trunk segments out (Fig. 3B): With a scalpel, trim a rectangular section of tissues surrounding the neural tube and the flanking somites and covering the last 5-6 somite pairs as well as the nascent pair in the anteriormost part of the unsegmented paraxial mesoderm. Transfer the trunk segments into DMEM in a 35-mm dish using forceps. Collect all trunk portions before the following step. Take great care to the axial level where the explant is taken out. Trimming should be done away from the somites in the lateral mesoderm to leave a trunk segment large enough for easy handling with forceps for transfer.

7. Preparing the culture dishes: On the back of the 35- or 60-mm dish or of 4-well plates, draw circles of about $1-\mathrm{cm}$ diameter with a marker pen to delineate the areas of the dish to be coated with extracellular matrix proteins. Fibronectin is routinely used as a coating protein. Deposit inside of each circle a 50-100 $\mu$ d drop of fibronectin at concentrations ranging from 1-100 $\mu \mathrm{g} / \mathrm{ml}$ (optimal coating concentration in plastic dishes being $10 \mu \mathrm{g} / \mathrm{ml}$ ). Coating of the dishes should last at least 45 minutes at $37^{\circ} \mathrm{C}$. Although neural crest cell cultures can in theory be performed on uncoated cell culturetreated dishes, it is appreciable to coat the dish with extracellular matrix proteins to speed up neural tube anchorage and neural crest cell outgrowth. For the reason explained above, to minimize the amount of culture medium used for culturing neural crest cells, we recommend to delineate restricted spots within the dish for receiving the culture wells into which the neural tube explants will be deposited. 


\section{Dissecting the neural tubes}

8. Preparing the dispase solution: Deposit a drop of $500 \mu \mathrm{l}$ of freshly-prepared dispase solution at $2.5 \mathrm{U} / \mathrm{ml}$ in DMEM in the lid of a 35- $\mathrm{mm}$ dish placed under the dissecting microscope. Dispase II is a bacterial neutral protease that offers a decisive advantage over trypsin in that it is stable and active at room temperature and does not require serum to be inactivated.

9. Aspirate the trunk explants in a 1,000- $\mu$ l pipette tip that has been cut in its end with straight scissors, enough (about 1-2 $\mathrm{mm}$ from the end) to allow their easy through passage, and transfer them into the dispase solution. Because the explants tend to stick to the plastic of the tip during aspiration and if so, cannot be easily retrieved, to prevent this, we strongly recommend to coat the inside of the tip with FCS at $0.5 \%$ in DMEM by repeated pipetting. Take care of not diluting too much the dispase solution by adding excessive amounts of DMEM $(<100 \mu \mathrm{l})$ together with the explants.

10. Incubate the trunk explants in dispase for about 5 minutes at room temperature. Remove the bulk of dispase solution with a $200-\mu 1$ pipette tip (but do not aspirate all of it), replace it by fresh DMEM and regularly monitor the explants aspects. When the neural tube becomes slightly wavy (generally within 5 min after rinsing), it is time to start the dissection. Important notice: the duration of explant incubation in dispase should not exceed 10 minutes as prolonged exposure ultimately affects the viability of tissues. However, we recommend not to aspirate entirely the dispase solution and leave approximately 50-100 $\mu \mathrm{l}$ (out of the initial $500 \mu \mathrm{l}$ ) before rinsing with DMEM, to maintain a minimal activity, thereby facilitating the manual dissection of the neural tube.

11. Dissecting the neural tubes (Fig. 4A): Under the dissecting microscope at zoom $3 \mathrm{x}$, place first the trunk segments dorsal side up. Then, while holding the explant in place with one of the minutien pins mounted on a pin holder with screw (therefater referred as dissection pins), introduce the other pin under the ectoderm and along the neural tube and gently peel the ectoderm off. Then separate the neural tube from the somites on either sides and discard the ectoderm, somites, and endoderm. Finally, if required, once all neural tubes have been dissected out, detach the notochord from each of them, starting from one extremity. At this step, identifying the dorsal side of the explant is less easy than before on the whole embryo. By manipulating the explant, it is however possible to define the dorsal side as the one where the neural tube is protruding externally and the ventral side as the one where the notochord is aligned with the neural tube. In most experiments, removing the notochord from the explants before transferring to the culture dish is optional. Indeed, as explained below, the notochord remains attached to the neural tube during most of the culture and does not hamper neural crest cell outgrowth. Moreover, it helps orienting the neural tube during deposition into the

culture wells. Important recommendations concerning the dissection procedure: First, the principle of the dissection relies primarily on the enzymatic action of dispase and more secondarily on the manual separation of the tissues. If tissues cannot be dissociated apart easily with the dissecting pins, it means that the enzymatic digestion is not complete and should last longer. It is then better to leave the explants still and wait for a moment prior to resuming dissection, rather than risking severe neural tube damage. Second, do not hesitate to customize the dissecting tools to your hands, e.g. a rigid, straight needle for holding the explant and a more flexible, bent-end needle, for trimming the tissues apart. Third, if you don't feel comfortable with the procedure shown on Fig. 4A, do not hesitate to make your own, provided you succeed in isolating the neural tube free of adjacent tissues and not damaged. Important, avoid to open the neural tube in its dorsal side as a book, as it will result in a poor neural crest cell outgrowth. 12. Aspirate the neural tubes with a $200-\mu \mathrm{l}$ pipette tip previously coated with $0.5 \%$ FCS and transfer them into DMEM-0.5\% FCS in a 35-mm dish for a 15-30 minutes recovery period at room temperature. Once dissected, avoid leaving the isolated neural tubes in the dispase 
solution for long. We suggest to dissect out about five to ten neural tubes at once (depending on your experience, speed and skill, but not many more), collect them and transfer them immediately into the DMEM-0.5\% FCS containing dish.

\section{Transferring the neural tube explants to the culture dish}

13. During the recovery period, rinse each fibronectin-coated spot in the culture dishes with DMEM and, if necessary, prepare the custom-made culture wells into which neural tube explants will be maintained in culture. Wells made from flexible assay plates with 96 flatbottom wells (Falcon 3912 MicroTest III flexible assay plate from Becton Dickinson) are easy to do, convenient, and cheap. They should be discarded at the end of the experiment. Cut each well out of the plate with straight sharp-end scissors, remove its bottom but keep its edges intact so as it can hold stably on the dish (see Fig. 4B). Wash the wells briefly in PBS followed by DMEM rinsing before using.

14. After removing the DMEM, place the wells over each fibronectin-coated spot in the culture dishes and fill them with $100 \mu \mathrm{l}$ of culture medium. For basic experiments, use DMEM supplemented with $2 \mathrm{mM}$ glutamine, $1 \%$ penicillin-streptomycin, and $1 \%$ FCS. Transfer neural tubes with a $200-\mu l$ pipette tip into each well, up to 5 neural tubes/well, taking care of not diluting too much the culture medium in the well. Under the dissecting microscope, arrange the neural tubes within the wells with the mounted dissection pins in order to keep them apart to avoid overlap of neural crest cell outgrowths (Fig. 4B). Place the dish in a humidified $37^{\circ} \mathrm{C}$, $5 \% \mathrm{CO}_{2}$ incubator. In addition to maintaining neural tubes in a low amount of medium, culture wells have the advantage of minimizing turbulences that might displace the explants during transferring to the incubator. Whenever possible, orientate the neural tubes with their ventral (i.e. lining the notochord) side up and their dorsal side in contact with the dish. This position is highly favorable for almost immediate dispersion of neural crest cells (see below). High serum concentrations are not required for obtaining maximal neural crest migration and survival and $1-5 \%$ generally suffice. If serum must be omitted from the culture medium, it is possible to culture neural crest cells in medium consisting of DMEM supplemented with $0.1 \%$ ovalbumin (weight/volume), transferrin and insulin, each at $10 \mu \mathrm{g} / \mathrm{ml}$, instead of FCS.

15. The following day, the culture wells can be removed gently to avoid detachment of the neural tubes, and the dish filled with fresh prewarmed medium before examination under an inverted microscope. If necessary, the neural tube can be removed from the culture dish either by gentle lifting of its end using mounted dissection pins, taking care of not making scratches in the plastic, or by flushing the medium with pipette tips. Neural crest cells can be maintained in culture for several days without change of medium.

\section{ADAPTATIONS FOR IMMUNOFLUORESCENCE LABELING AND VIDEOMICROSCOPY}

The above basic protocol is designed to generate a typical outgrowth of neural crest cells suitable for a large variety of studies: immunolabeling and imaging analyses, in situ hybridization, videomicroscopy, biochemical approaches and functional assays. However, adaptations to this protocol are required for the type of culture dish to be utilized in the cases of immunofluorescence and videomicroscopy investigations.

\section{Immunofluorescence labeling of cells}

Material:

Because of the poor optic qualities of most plastic dishes, neural crest cell cultures should be performed on glass coverslips for immunofluorescence analyses. Utilization of square 
coverslips of $18 \times 18 \mathrm{~mm}$ or round coverslips of 10 or $12 \mathrm{~mm}$ diameter is particularly suitable because their area and size fit well in multiwell plates and can accomodate all types of culture wells.

Protocol:

Clean coverslips with ethanol to remove any grease residues, rinse them in PBS, and coat them with fibronectin at $20 \mu \mathrm{g} / \mathrm{ml}$ instead of $10 \mu \mathrm{g} / \mathrm{ml}$, knowing that the yield of fibronectin adsorption on glass is lower than on plastic. Place the glass coverslips into 35- or 60-mm dishes or in multiwell plates and proceed to the culture as described in the basic protocol. Use preferably multiwell plates with one coverslip per well to exclude any possible overlapping between coverslips. In addition, these plates can be used for the blocking and rinsing steps of the immunolabeling procedure. An alternative is to use 4- or 8-well plates with glass bottom specifically designed for immunofluorescence studies ( $\mu$-slide chambers from Ibidi, cat. no. 80427 and 80827, or Lab-Tek chambers from Nunc, cat. no. 154526 and 154534).

\section{Videomicroscopy}

Due to their size and shape, culture wells do not permit optimal phase-contrast microscopic observations of neural crest cells and therefore cannot be used for videomicroscopy. Several options are possible anyway.

\section{Protocol 1:}

If analyses have to be performed on the initial steps of neural crest cell migration (i.e. during the first 10-12 hours), we strongly recommend to utilize Terasaki 60-well plates, available from many different local resellers. Their flat-bottom wells are adapted to inverted microscopy and they are suited for culturing individual neural tube explants in a limited amount of medium (15 $\mu \mathrm{l})$. Coat each well with $15 \mu \mathrm{l}$ of fibronectin at $10 \mu \mathrm{g} / \mathrm{ml}$ in PBS and after rinsing with DMEM, add $20 \mu \mathrm{l}$ of culture medium so as to make a dome at the surface of the well. Avoid absolutely medium leaking out of the wells, otherwise the subsequent steps are compromised. Deposit gently one neural tube per well, orientate it appropriately in the well, add very gently over the culture medium a glass coverslip, being very carefully to avoid air bubbles being trapped between the glass and the medium in the well, and cover the plate with its lid. The glass coverslip ensures excellent phase contrast optics and prevents rapid evaporation of the medium. Under these conditions, the neural tube culture can be visualized by videomicroscopy and maintained for prolonged time period up to 12 hours at $37^{\circ} \mathrm{C}$ in a humidified atmosphere. However, Terasaki plates cannot be used for long term cultures of neural crest cells for two main reasons. First, because the medium is limited in amount in each well, it may become rapidly exhausted by highly-proliferating cells. Second, actively- migrating neural crest cells rapidly cover entirely the bottom of the well and reach its edges.

\section{Protocol 2:}

If long-term migration (up to 24 hours) has to be investigated, several companies have developed many device and designed a large variety of dishes optimized for videomicroscopy analyses. We recommend to use the " $\mu$-Slide Angiogenesis" from Ibidi (cat. no. 81506), a plate with 15 wells particularly adapted for neural tube explants. Each well contains up to $50 \mu \mathrm{l}$ of culture medium and are designed to eliminate meniscus formation, thereby favoring phase contrast visualization. $\mu$-Slide 8 Well also from Ibidi (cat. no. 80826) are a good alternative, offering the possibility to track several explants in each well. Finally, it is possible to use the 4or 8-well plates with glass bottom designed for immunofluorescence studies mentioned above also for videomicroscopic analyses. Interestingly, these slides are fitted for live imaging using high resolution objectives and may be combined with immunofluorescence microscopy. An important issue when doing videomicroscopy is to provide optimal conditions for 
maintaining cell survival throughout the course of the recording. Survival in culture is affected by inadequate temperatures (both excessive and insufficient), $\mathrm{pH}$ (acidic or alkaline), or osmolarity due to the absence of thermostat, inappropriate $\mathrm{CO}_{2}$ concentrations or medium evaporation. This remains particularly challenging for neural crest cell cultures as it must accommodate several often antagonistic constraints regarding the volume of culture medium. Having access to a high-resolution phasecontrast microscope with a motorized stage and equipped with a heated chamber connected to temperature and gas controlling systems is therefore required. Otherwise, a few simple adjustments may help to compensate for the lack of these device but only for relatively short-term recordings : adding Hepes at $25 \mathrm{mM}$ may temporarily maintain the $\mathrm{pH}$ at acceptable levels and adding mineral oil over the culture medium may prevent too rapid evaporation.

\section{COMMENTARY}

\section{Time considerations}

Of course, the timing for preparing neural crest cell cultures depends largely on the number of eggs to work with and on the experience and technical skill of the experimenter. Generally consider that three hours, maximum four hours for beginners, is necessary to collect the embryos from the egg, isolate the trunk fragments, dissect the neural tubes and transfer them into culture using some 50 eggs. Preferably, start the experiment in the morning; this give enough time to get initiation of neural crest cell migration in the early afternoon to set the experimental conditions for functional studies or for videomicroscopy. Night owls should not be discouraged, however, and should start at the desired time that is most appropriate for them!

\section{Phenotypic characterization of neural crest cells during the first 24 hours in culture}

Collective behavior and morphological features of neural crest cells in culture

At variance to many other embryonic tissues which spread out gradually on the dish to form large uniform monolayers, neural tubes evolve in culture in a strikingly-different way, characterized by a very rapid kinetics of cell dispersion, due primarily to the very active migratory potential of neural crest cells combined with a high proliferation rate. Several scenarios must, however, be considered depending on the initial conformation of the neural tube onto the dish. When the neural tube lies dorsally on the substratum (Fig. 5A), a row of protruding neural crest cells appears on either side of the explant, first in its anteriormost portion, almost immediately after its initial anchorage to the dish (i.e. within an hour or so after the beginning of the culture). After 2-3 hours, both sides of the neural tube are entirely lined throughout the rostrocaudal axis by several rows of spread and cohesive neural crest cells (Fig. 5B1). During the subsequent 10-12 hours, the neural crest population expands rapidly and steadily away from the neural tube, forming after 24 hours a large halo of 1-2 mm wide composed of about 1,000-2,000 cells distributed evenly around the neural tube (Fig. 5A2- A4). If the neural tube interacts initially with the substratum through one of its lateral sides (Fig. 5B), neural crest cells are seen dispersing onto the dish only after a 2-4 hours delay. The first delaminating cells are arranged as clumps of round cells attached to the dorsal border of the neural tube and it is only progressively that they spread out on the substratum and form several rows of cells migrating away (Fig. 5B1-B2). In the opposite ventral side of the neural tube, in contrast, virtually no neural crest cell can be detected along the notochord. After 24 hours, the entire neural crest cell population is contiguous to the dorsal side of the neural tube where they form a large outgrowth of spread cells essentially as in the previous configuration, whereas the other side is almost entirely free of any dispersing cells (Fig. 5B3). 
It should be noted, however, that in most situations, the neural tube explant is neither strictly oriented dorsoventrally on the dish nor lying precisely on its lateral side. As a result, neural crest cells emerge on either sides of the neural tube but in different amounts and at slightly different timings, forming after 24 hours a cell population asymmetrically-distributed around the neural tube. At the cellular level, neural crest cells display morphological traits strikingly different from those of other embryonic cells cultured on two-dimensional substrates. Although they exhibit a great diversity of cell shapes related to their dynamics of locomotion, they can be easily discriminated from other embryonic cells, e.g. from contaminating mesodermal cells that remained attached to the neural tube after dissection. On fibronectin substrates, they rarely show a bipolar aspect characteristic of sparse motile fibroblasts, with a broad lamellipodium at the leading edge and thin trailing edge. Instead, they present alternatively round, elongated or stellate shapes with restricted intercellular contacts, despite a high cell density (Fig. 5C). Quite remarkably, the neural tube itself does not spread onto the substratum during the first 24 hours of culture. Instead, it retains its compact hollow tube shape whose lumen is visible by transparence along the explant length (a striking example is shown in Fig. 6A1). In addition, the explant presents sharp limits and is surrounded with no transition by the neural crest outgrowth. Only in its rostral and caudal extremities, some neural tube cells become organized as monolayers of densely-packed epitheloid cells, as a result of a woundhealing response provoked during explant trimming. Therefore, neural tube explants comprise two strictlysegregated cell populations, dispersing neural crest cells at the periphery and the intact neural tube in the center. Because of this particularity, the neural tube can be easily removed manually from the dish leaving behind a pure intact population of neural crest cells (Fig. 5D).

Characterizing neural crest cell phenotype in culture using cell lineage markers

Neural crest cell identity in culture can be ascertained using a number of cell lineage markers which can be conveniently detected by immunofluorescence staining and by in situ hybridization (Table I).

To date, Sox-10 constitutes the most universal marker for neural crest cells at the time of their outward migration from the neural tube. Sox-10 is a member of the SoxE subclass of highmobility-group domain-containing Sox transcription factors which plays a critical role in the maintenance of the progenitor/stem cell state of neural crest cells (Hong and Saint-Jeannet, 2005; Weider and Wegner, 2017). It exists in all vertebrates examined so far, from lamprey to human, and it is expressed at all axial levels by neural crest cells at the time of their segregation from the neural tube and during their subsequent migration to their target sites (Hockman et al., 2019; Williams et al., 2019). In culture, Sox-10 shows essentially the same expression pattern in neural crest cells as in the embryo. Both its transcripts and proteins are expressed by virtually all neural crest cells immediately at the time when they segregate from the neural tube (Fig. 6A1, B2). Interestingly, Sox-2, another member of the Sox family of transcription factors, also involved in cell stemness but for neural epithelial cells, shows the converse expression pattern to Sox-10. It is expressed in neural tube cells but not in neural crest cells, whether they are delaminating or migrating (Fig. 6A2, B3).

Snail-2 is an interesting marker that complements Sox-10 and Sox-2 for tracing and characterizing neural crest cells in culture. Snail-2 is a member of the Snail family of Znfinger transcription factor which operates as a master gene for initiation of the epithelium to mesenchyme transition process both during embryogenesis and adulthood (Nieto, 2002). During neural crest cell development, Snail-2 drives very precociously the specification of neural crest progenitors and controls their subsequent delamination from the neural tube, but it plays no known role during migration (Duband et al., 2015). Unlike Sox-10 which is expressed continuously in migrating neural crest cells at all steps of their dispersion, Snail-2 expression pattern varies with time in culture. In neural tube explants cultured for less than 6 hours, when 
neural crest cell emigration culminates, it is expressed both in premigratory neural crest cells located in the neural tube and, at slightly lower levels, in most migrating cells, together with Sox-10. In contrast, in explants cultured for 24 hours, when neural crest cell delamination is almost terminated, Snail-2 is restricted to a few neural crest cells that are still in the process of delamination in the posterior portion of the neural tube, and it is notably absent from the vast majority of migrating neural crest cells (Fig. 6A1, B1). Intriguingly, the Snail-2-positive contingent of premigratory neural crest cells that have not yet undergone complete segregation from the neural tube is devoid of both Sox-10 and Sox-2 (Fig. 6A2). Thus, Snail-2 and Sox-10 define several subpopulations of neural crest cells at different steps of their development during the first day in culture: the Snail-2+, Sox-10-premigratory cells, the Snail-2+, Sox-10+ delaminating and early migrating cells, and the Snail-2-, Sox-10+ late migrating cells.

The human natural killer-1 (HNK-1) epitope represents another interesting neural crest cell marker that has been widely used in avian species. HNK-1 is historically the first marker for migrating neural crest cells to be identified (Vincent and Thiery, 1984). It consists of a glucidic moiety harbored by various cell surface components, including lipids and celladhesion molecules of the Ig superfamily (Tucker et al., 1984). In culture of avian trunk neural tube explants, the HNK-1 epitope is expressed by migrating neural crest cells but not in premigratory cells. It decorates the entire cell surface, making it a very convenient tool for a rapid survey and characterization of cultured neural crest cells (Fig. 6A3). However, caution is needed in interpreting HNK-1 immunostaining for several reasons. First, HNK-1 is barely detectable on neural crest cells during the first 4-6 hours after initiation of migration. Second, despite a widespread expression in 24-hours cultures, not all neural crest cells (about 10-20\%) express high levels of HNK-1, making it an adequate tool to characterize neural crest cells at the population level but not at the single cell level. Third, although it is conspicuous in migrating neural crest cells, HNK-1 may be detected on the surface of other cells at the same developmental stage (Vincent and Thiery, 1984; Newgreen et al., 1990). Notably, the extracellular matrix surrounding the notochord, but not notochordal cells themselves, display strong HNK-1 staining both in vivo and in culture. Finally, HNK-1 is not suitable for neural crest cell studies in all vertebrates. Beside chick and quail, it can be used successfully to label migrating neural crest cells in dog, pig and human, but it is not present on migrating neural crest cells in amphibians or mice and is found only transiently on neural crest cells of rats (Tucker et al., 1988). Therefore, it is important to consider carefully the tissue and species of interest and the timing of development before concluding on the neural crest origin of cells based on the HNK-1 staining.

Using additional neural crest markers may prove to be necessary. Other less-commonly used markers may help refining the characterization of neural crest cells in culture. These include Foxd-3, a member of the forkhead family of transcription factors, involved like Sox-10 in the stem cell renewal and pluripotency of neural crest cells (Liu and Labosky, 2008). In vivo as well as in culture, as judged on in situ hybridization analyses, Foxd-3 exhibits grossly the same expression pattern as Sox-10 in delaminating and early migrating neural crest cells. However, in 24-hour cultures, a significant proportion of the neural crest cell population is negative for Foxd-3 (Fig. 6B4), reflecting their engagement in the melanocytic lineage, known to require combined maintenance of Sox-10 expression and Foxd-3 repression (Thomas and Erickson, 2009).

Finally, beside cell lineage markers, cell-adhesion molecules are also instrumental to analyze neural crest cell development in culture. Cadherin-6B and N-cadherin, two members of the cadherin family of cell-cell adhesion molecules, can in particular discriminate premigratory neural crest cells from both neural epithelial cells and migrating neural crest cells, constituting useful alternatives to Snail-2, Sox-10 and Sox-2 (Fig. 6B5, B6)(Dady and Duband, 2017). 
Numerous other possible markers for neural crest cells have been reportedly used in vivo or in vitro, such as the p75 low affinity nerve growth factor receptor (p75-NGFR), nestin, Msx-1, Twist-1, Pax-3, AP-2 $\alpha$, cMyc, Id-1 or Ets-1, to name a few (Dupin and Sommer, 2012; Soldatov et al., 2019; Williams et al., 2019). Notwithstanding their interest and potential, these markers have been less frequently used or simply cannot be used to characterize avian trunk neural crest cells in culture. Some of them are not found in trunk neural crest cells, but rather are specific to cranial neural crest (e.g. Id-1 and Ets-1), some are not found in avians but in mouse (p75NGFR) or in Xenopus (Twist-1), some are expressed in restricted neural crest cell subsets (Msx1) or conversely are found in other cell types (Pax-3, AP-2 $\alpha, \mathrm{cMyc})$, while others are not expressed in neural crest cells but are used mostly for stem cell analyses (nestin). We therefore recommend to use them for specific studies.

Tracking neural crest cell migration in culture using videomicroscopy

The spontaneous migratory behavior of neural crest cells is certainly one of the most challenging and fascinating issues of their ontogeny which attracted strong interest from both cell and developmental biologists. Strikingly, unlike many other cell migration systems developed in vitro, neural crest cell migration can be recapitulated in culture without any experimental artifice and without the assistance of migration-stimulating factors in the culture medium. In addition, it is one of the few systems in which the contribution of both collective behavior and individual cell locomotion can be tackled simultaneously for a comprehensive understanding of population cell displacement. Thus, even though culturing neural crest cells on two-dimensional substrates does not mimic entirely their native embryonic environment in its biochemical, physical and temporal complexity, considerable information have been gathered owing to this system on how interactions between extracellular matrix components and their cell surface integrin receptors and the organization of the cytoskeletal locomotory machinery drive cell migration (Newgreen et al., 1982; Rovasio et al., 1983; Duband et al., 1986). In addition, it led to new interesting concepts on how cell-cell contacts and maintenance of a high cell density may maximize cell migration (Rovasio et al., 1983; Thomas and Yamada, 1992). Quite remarkably, it is only recently that these data and models were confirmed in in vivo imaging studies at high resolution ( $\mathrm{Li}$ et al., 2019), thereby validating the in vitro approach and emphasizing its interest and prospects.

Avian trunk neural crest cell migration in culture can be quantified by simple measurements either of the linear distance between the edge of the neural tube and the rim of the neural crest outgrowth (preferably at the midportion of the neural tube explant) or of the area of the outgrowth. Both parameters provide an accurate estimate of the extension of the neural crest cell population over time, but it should be stressed that they do not provide details on individual cell adhesion and locomotion, on cellular interactions among the population as well as on other cellular events such as cell proliferation which all have a strong impact on the final outcome. This is particularly critical in functional studies resulting either in a population of denselypacked cells occupying a limited area along the neural tube or in a large outgrowth composed of sparse clusters of round cells distributed away from the neural tube. In both cases, although values for distance and area are at odds, the migration of the whole population is largely compromised but due to different cellular events affected. The distance and area parameters should then be used as a first approximate and be completed with more systematic videomicroscopy analyses, giving access to the whole range of individual and collective features. If long term migration of the whole neural crest cell population is to be analyzed, timelapse videomicroscopy should be performed with a 10x objective and images captured every 5 minutes during 12-24 hours. For analysis of the dynamics of cellular protrusion in individual cells, it is preferable to use at least 20x objectives and images should be recorded every 15 or 20 seconds during at least 15 minutes. As mentioned above, the use of a 
thermostatically-controlled chamber coupled with a $\mathrm{CO}_{2}$ controller mounted on a motorized stage is strongly recommended to avoid any artifact that may alter the quality of the recordings and affect measurements. Fig. 7 and Video 1 illustrate an example of an avian trunk neural crest cell outgrowth dispersing under standard conditions for about 16 hours. Image analyses using appropriate softwares, e.g. MetaMorph (2M's), provide data on the positions of individual cells along the $\mathrm{X}$ and $\mathrm{Y}$ axes for each image and the distance covered by cells between two consecutive images, two parameters necessary for cell tracking (Fig. 7A). From these data, it is possible to deduce the speed of locomotion of individual cells and the persistence of their movement (i.e. the ratio between the linear distance between two positions and the actual distance covered) over time (Fig. 7B, C). Additional parameters can also be appreciated using this technique and analyzed using MetaMorph or ImageJ softwares: individual cell shape (area, perimeter, Ferret, compactness, shape index), cell-cell contacts between neighbors (length of intercellular contacts), or cell division (proportion of dividing cells, duration of cell cycle). Results show that avian trunk neural crest cells migrate as individuals and not as a cohesive layer or as chains as observed for cranial or enteric neural crest cell populations. Movement of individual cells is not uniform as in isolated fibroblasts. Rather it consists of short periods of linear, intense and fast cell displacement involving a unique large pseudopode followed by stationary phases where the cell exhibits a stellate shape. Movement resumes with retraction of most cell processes and cellular elongation with formation of a single pseudopode. Importantly, both locomotion and directionality are driven essentially by cell-cell contacts and mechanical forces resulting from high cell density. Thus, when an individual cell moves ahead of the rest of the population, either it moves back to rejoin the rest of the population as a result of coattraction (Carmona-Fontaine et al., 2011) or it stops and will resume migrating only after being reached and contacted by followers, a process that has been referred as to contact stimulation of movement (Thomas and Yamada, 1992).

Several attempts have been made over the years to adapt the two-dimensional neural crest cell culture system for investigating the influence of the environment and its physical aspects on neural crest cell migration. For instance, creating alternating stripes consisting of plastic dish coated or not with extracellular matrix material, or containing attractive or repulsive factors was used to analyze space constraints or guidance mechanisms involved in neural crest cell migration (e.g. see Rovasio et al., 1983; Wang and Anderson, 1997). Likewise, in pioneering

studies using Nucleopore filters with pore diameters of varying sizes, Newgreen (1989) could evaluate the ability of neural crest cells to invade restricted cell-free spaces. To date, the emergence of elaborated, controled technologies to generate two- or three-dimensional micropatterned substrates with defined chemical and physical specificities associated with highly-sensitive methods for measuring molecular interactions and physical parameters open new avenues to tackle in a reliable, less empiric way the mechanical properties of neural crest cells during migration (Trichet et al., 2012; Vedula et al., 2012).

\section{Phenotypic characterization of neural crest cells in long-term culture}

Culturing neural crest cells also proved to be source of valuable data concerning the issue of the differentiation capacities of individual neural crest cells (Dupin et al., 2018). Indeed, while neural crest cells display a relatively-uniform aspect and collective behavior during the first day in culture, after 24 hours, important changes appear in the overall organization of the population and in individual cell morphologies. The first and most obvious event to occur is a massive neurite outgrowth from the neural tube especially in its ventral side (Fig. 8A). This illustrates the fact that the neural tube is able to pursue its own developmental program into a spinal cordlike structure, in synchrony with that of neural crest cells. These neurites derive most likely from motor neurons, migrate on top of neural crest cells, ultimately covering them entirely. However, contrary to what happens in the embryo, neurites in culture do not organize as bundles 
as soon as they emerge out of the neural tube explant. Other alterations can be seen both at the periphery of the neural crest outgrowth and more centrally near the neural tube after the second day of culture (Fig. 8B). Large spread fibroblasts develop at the periphery while small individual neurons appear more centrally. Progressively, other cell types characterized by their own specific morphologies can be detected, often as clones, among the neural crest cell outgrowth. This includes melanoblasts with a small compact cell body and long thin processes, and glial cells with a larger cell body and long thicker cellular extensions, reminiscent of astrocytes. Terminal differentiation occurs generally later after 5-7 days in culture, as evidenced for example by the deposition of dark melanin in melanocytes. Therefore, differentiation of neural crest cells can be successfully achieved in culture, yielding the various cell types that are normally derived from trunk neural crest cells in vivo (neurons, glia, melanocytes). In addition to them, mesenchymal cells, a derivative normally obtained with cranial neural crest only, are also produced in culture, thereby revealing that trunk neural crest cells harbor mesenchymal fibroblastic capacities which can be uncovered in vitro. Of note, this diversity of cell types is also observed when the neural tube has been removed from the culture, indicating that these changes are intrinsic to neural crest cells and are not driven primarily under a neural tube influence. Neural crest cell differentiation can be followed using specific cell lineage markers in classical immunolabeling experiments (Table I). The ?-smooth muscle actin (SMA) isoform is present in the large fibroblastic cells as an elaborated cytoplasmic meshwork, assessing their myofibroblast identity (Fig. 8C1). Likewise, ?lIII-tubulin, the neuron-specific tubulin isoform recognized by the Tuj-1 antibody, is strongly expressed in individual neurons both in the neurites and in the cell body (Fig. 8C2). MITF, a transcription factor involved in melanocyte determination, is conspicuous in nuclei of melanoblasts (Fig. 8C3) while the glia fibrillary acidic protein (GFAP) and the brain lipid binding protein (BLBP) are both found in the cytoplasm of differentiating glial cells (not shown). Interestingly, expression of the early neural crest cell markers Sox-10 and HNK-1 also evolves during cell lineage diversification.

While a substantial number of cells retain their typical stellate morphology associated with strong Sox-10 and HNK-1 labelings, revealing the maintenance of an important pool of neural crest progenitors throughout the culture (Fig. 8C4), differentiating cells express either Sox-10 (melanoblasts and glial cells) or HNK-1 (neurons) or neither (myofibroblasts), together with their specific differentiation markers. However, occasionally, both Sox-10 and HNK-1 may coexist with SMA or MITF in cells (Fig. 8C1, C3), albeit at lower levels than in undifferentiated neural crest cells. These cells are likely to represent intermediate steps between progenitors to fully differentiated cells.

It should be stressed that although trunk neural crest cell differentiation occurs spontaneously in culture in basic medium with $1 \%$ serum, neither the extent of cell differentiation nor the ratio between the various cell types can be mastered easily in these conditions. To this aim, it is necessary to add exogeneous growth factors or morphogens to the culture medium to help orienting neural crest cell fates toward specific lineages (Dupin et al., 2018). For instance, TGFbeta promotes a myofibroblastic phenotype at the expense of a neuronal one, BMP-2, neuregulin, endothelin-3 and Shh stimulate differentiation into autonomic neurons, glia, melanocytes and chondrocytes, respectively, while Wnt-1 and BMP in combination favor maintenance of neural crest cells in a progenitor state. Ideally, to study neural crest cell multipotency and differentiation capacities, in vitro cloning of individual cells on feeder layers and in optimized culture conditions is the best option (Dupin et al., 2018).

\section{Concluding remarks}

The protocol for culturing avian trunk neural crest cells presented here derives from the method initially devised by Cohen and Konigsberg and later by Sieber-Blum and Cohen (Cohen and Konigsberg, 1975; Sieber-Blum and Cohen, 1980) to generate neural crest cell clones and study 
their differentiation potential. Since then, this technique has been applied to trunk neural crest cells from other species, notably mouse, rat and human (Stemple and Anderson, 1992; Ito and Sieber-Blum, 1993; Thomas et al., 2008; Etchevers, 2011). In parallel, other methods based sometimes on different approaches have been developed to produce in vitro cultures of neural crest cells from other axial levels. Thus, cranial neural crest cells can be retrieved from embryos at stage HH9 (6-8 somites) using either whole neural tubes dissected at midbrain and anterior hindbrain levels or after extirpation of the neural folds only (Calloni et al., 2007). Another strategy is to dissect out cranial neural crest cells during the course of their lateral migration under the ectoderm in embryos at stage 10- 11 (10-12 somites) (Ziller et al., 1983). Using the same principle of extirpation, cranial neural crest cells from the Xenopus embryo have also been the matter of intense in vitro studies (Scarpa et al., 2015; Cousin and Alfandari, 2018). These techniques all produce neural crest cells with migration and differentiation capacities, but it should be stressed that they are generally more challenging and less accessible to the beginners due to some inherent technical constraints and hurdles. For example, mouse neural tubes can be dissected only with difficulty because of the reduced size of the embryo as well as its curved, compact shape. In addition, collecting many neural tubes at the same developmental stage in mouse is costly and necessitates many pregnant mice because embryos in the same litter often grow at different speeds. Neural crest cells at cranial levels are also difficult to collect even in birds for similar reasons: embryos at stage 9 or 11 are comparatively much smaller and more fragile than at stages 13-15, and the neural tube or the neural folds cannot be easily dissected out free of the ectoderm because at these stages, both tissues are not yet segregated. In addition, contrary to trunk neural tubes which can be obtained from embryos at several embryonic stages, the time window to collect cranial neural tubes is very narrow. Finally, unlike avian neural crest cells which can be grown in minimal medium with as less as $1 \%$ serum or even in serum-free medium, culture medium for mammalian neural crest cells requires several additives, such as fibroblast growth factor or leukemia inhibitory factor, for optimal cell survival (Etchevers, 2011). For all these reasons, we therefore recommend to start with avian trunk neural crest cells and, once all the technical difficulties have been solved, to switch to another neural crest cell population or to another animal model when relevant. Neural crest cells derived from other animal species or from other axial levels often differ from avian trunk neural crest cells by several features. In mouse for example, neural crest cells are produced in lesser numbers and more slowly, and their migration behavior can be examined only after 24 hours in culture (Gonzalez Malagon et al., 2019). Xenopus cranial neural crest cells do not migrate individually and randomly, instead they form highly cohesive structures migrating collectively by a mechanism driven by contact-inhibition of movement as well as coattraction (Carmona-Fontaine et al., 2008; Carmona-Fontaine et al., 2011). Finally, at variance to most other species, human neural crest cells show the unique ability to persist and self-renew in culture as progenitors for prolonged periods and can be replated many times as established cell lines (Thomas et al., 2008).

With the spectacular development of the stem cell field, the last decade witnessed the establishment of several procedures to produce neural crest stem cells from embryonic, fetal and adult tissues. Thus, the use of embryonic stem cells, induced puripotent stem cells, neuroepithelial "crestospheres" that self-renew and retain multipotency for weeks, or reprogrammed cells from adult teeth, skin or nerves proved to be extremely potent, in particular for generating large amounts of cells usable for comprehensive large scale analyses, such epigenomic and transcriptome profiling (Kerosuo et al., 2015; Prescott et al., 2015; Liu and Cheung, 2016; Bajpai et al., 2017; Mohlin et al., 2019). Mastering primary cultures of neural crest cells certainly provides the fundamentals and the knowledge for developing these sophisticated approaches. 


\section{ACKNOWLEDGMENTS}

Work from the authors is supported by INSERM, the Université Paris-Est Créteil and the Fondation ARC pour la Recherche contre le Cancer.

\section{LITERATURE CITED}

Baggiolini A, Varum S, Mateos JM, Bettosini D, John N, Bonalli M, Ziegler U, Dimou L, Clevers H, Furrer R, Sommer L. 2015. Premigratory and migratory neural crest cells are multipotent in vivo. Cell Stem Cell 16:314-322.

Bajpai VK, Kerosuo L, Tseropoulos G, Cummings KA, Wang X, Lei P, Liu B, Liu S, Popescu GK, Bronner ME, Andreadis ST. 2017. Reprogramming Postnatal Human Epidermal Keratinocytes Toward Functional Neural Crest Fates. Stem Cells 35:1402-1415.

Betancur P, Bronner-Fraser M, Sauka-Spengler T. 2010. Assembling neural crest regulatory circuits into a gene regulatory network. Annu Rev Cell Dev Biol 26:581-603.

Calloni GW, Glavieux-Pardanaud C, Le Douarin NM, Dupin E. 2007. Sonic Hedgehog promotes the development of multipotent neural crest progenitors endowed with both mesenchymal and neural potentials. Proc Natl Acad Sci USA 104:19879-19884.

Carmona-Fontaine C, Matthews HK, Kuriyama S, Moreno M, Dunn GA, Parsons M, Stern CD, Mayor R. 2008. Contact inhibition of locomotion in vivo controls neural crest directional migration. Nature 456:957-961.

Carmona-Fontaine C, Theveneau E, Tzekou A, Tada M, Woods M, Page KM, Parsons M, Lambris JD, Mayor R. 2011. Complement fragment C3a controls mutual cell attraction during collective cell migration. Dev Cell 21:1026-1037.

Cheung M, Chaboissier M-C, Mynett A, Hirst E, Schedl A, Briscoe J. 2005. The transcriptional control of trunk neural crest induction, survival, and delamination. Dev. Cell 8:179-192.

Cohen AM, Konigsberg IR. 1975. A clonal approach to the problem of neural crest determination. Dev. Biol. 46:262-280.

Cousin H, Alfandari D. 2018. Cranial Neural Crest Explants. Cold Spring Harb Protoc 2018. Dady A, Duband JL. 2017. Cadherin interplay during neural crest segregation from the non-neural ectoderm and neural tube in the early chick embryo. Dev Dyn 246:550-565.

Duband J-L, Blavet C, Jarov A, Fournier-Thibault C. 2009. Spatio-temporal control of neural epithelial cell migration and epithelium-to-mesenchyme transition during neural tube development. Dev. Growth Diff. 51:25-44.

Duband J-L, Rocher S, Chen W-T, Yamada KM, Thiery JP. 1986. Cell adhesion and migration in the early vertebrate embryo: Location and possible role of the putative fibronectin-receptor complex. J. Cell Biol. 102:160-178.

Duband JL, Dady A, Fleury V. 2015. Resolving time and space constraints during neural crest formation and delamination. Curr Top Dev Biol 111:27-67.

Dupin E, Calloni GW, Coelho-Aguiar JM, Le Douarin NM. 2018. The issue of the multipotency of the neural crest cells. Dev Biol 444 Suppl 1:S47-S59.

Dupin E, Coelho-Aguiar JM. 2013. Isolation and differentiation properties of neural crest stem cells. Cytometry A 83:38-47.

Dupin E, Sommer L. 2012. Neural crest progenitors and stem cells: from early development to adulthood. Dev Biol 366:83-95.

Etchevers H. 2011. Primary culture of chick, mouse or human neural crest cells. Nat Protoc 6:15681577.

Furlan A, Adameyko I. 2018. Schwann cell precursor: a neural crest cell in disguise? Dev Biol 444 Suppl 1:S25-S35.

Gonzalez Malagon SG, Dobson L, Munoz AML, Dawson M, Barrell W, Marangos P, Krause M, Liu KJ. 2019. Dissection, Culture and Analysis of Primary Cranial Neural Crest Cells from Mouse for the Study of Neural Crest Cell Delamination and Migration. J Vis Exp. (152).

Hamburger V, Hamilton HL. 1951. A series of normal stages in the development of the chick embryo. J. Morph. 88:49-92. 
Hockman D, Chong-Morrison V, Green SA, Gavriouchkina D, Candido-Ferreira I, Ling ITC, Williams RM, Amemiya CT, Smith JJ, Bronner ME, Sauka-Spengler T. 2019. A genome-wide assessment of the ancestral neural crest gene regulatory network. Nat Commun 10:4689.

Hong CS, Saint-Jeannet JP. 2005. Sox proteins and neural crest development. Semin Cell Dev Biol 16:694-703.

Ito K, Sieber-Blum M. 1993. Pluripotent and developmentally restricted neural-crest-derived cells in posterior visceral arches. Dev. Biol. 156:191-200.

Kerosuo L, Nie S, Bajpai R, Bronner ME. 2015. Crestospheres: Long-Term Maintenance of Multipotent, Premigratory Neural Crest Stem Cells. Stem Cell Reports 5:499-507.

Le Douarin NM, Kalcheim C. 1999. The Neural Crest. New York: Cambridge University Press, Second Edition.

Li Y, Vieceli FM, Gonzalez WG, Li A, Tang W, Lois C, Bronner ME. 2019. In Vivo Quantitative Imaging Provides Insights into Trunk Neural Crest Migration. Cell Rep 26:1489-1500 e1483.

Liu JA, Cheung M. 2016. Neural crest stem cells and their potential therapeutic applications. Dev Biol 419:199-216.

Liu Y, Labosky PA. 2008. Regulation of embryonic stem cell self-renewal and pluripotency by Foxd3. Stem Cells 26:2475-2484.

Mohlin S, Kunttas E, Persson CU, Abdel-Haq R, Castillo A, Murko C, Bronner ME, Kerosuo L. 2019. Maintaining multipotent trunk neural crest stem cells as self-renewing crestospheres. Dev Biol 447:137 146.

Nakagawa S, Takeichi M. 1995. Neural crest cell-cell adhesion controlled by sequential and subpopulation-specific expression of novel cadherins. Development 121:1321-1332.

Newgreen DF. 1989. Physical influences on neural crest cell migration in avian embryos: Contact guidance and spatial restrictions. Dev. Biol. 131:136-148.

Newgreen DF, Gibbins IL, Sauter J, Wallenfels B, Wütz R. 1982. Ultrastructural and tissue-culture studies on the role of fibronectin, collagen and glycosaminoglycans in the migration of neural crest cells in the fowl embryo. Cell Tiss. Res. 221:521-549.

Newgreen DF, Powell ME, Moser B. 1990. Spatiotemporal changes in HNK-1/L2 glycoconjugates on avian embryo somite and neural crest cells. Dev. Biol. 139:100-120.

Nieto MA. 2002. The Snail superfamily of zinc-finger transcription factors. Nat. Rev. Mol. Cell Biol. 3:155-166.

Nieto MA, Sargent MG, Wilkinson DG, Cooke J. 1994. Control of cell behavior during vertebrate development by Slug, a zinc finger gene. Science 264:835-839.

Park KS, Gumbiner BM. 2012. Cadherin-6B stimulates an epithelial mesenchymal transition and the delamination of cells from the neural ectoderm via LIMK/cofilin mediated non-canonical BMP receptor signaling. Dev Biol 366:232-243.

Prescott SL, Srinivasan R, Marchetto MC, Grishina I, Narvaiza I, Selleri L, Gage FH, Swigut T, Wysocka J. 2015. Enhancer divergence and cis-regulatory evolution in the human and chimp neural crest. Cell 163:68-83.

Rovasio RA, Delouvée A, Yamada KM, Timpl R, Thiery JP. 1983. Neural crest cell migration: Requirements for exogenous fibronectin and high cell density. J. Cell Biol. 96:462-473.

Scarpa E, Szabo A, Bibonne A, Theveneau E, Parsons M, Mayor R. 2015. Cadherin Switch during EMT in Neural Crest Cells Leads to Contact Inhibition of Locomotion via Repolarization of Forces. Dev Cell 34:421-434.

Sieber-Blum M, Cohen AM. 1980. Clonal analysis of quail neural crest cells: They are pluripotent and differentiate in vitro in the absence of noncrest cells. Dev. Biol. 80:96-106.

Soldatov R, Kaucka M, Kastriti ME, Petersen J, Chontorotzea T, Englmaier L, Akkuratova N, Yang Y, Haring M, Dyachuk V, Bock C, Farlik M, Piacentino ML, Boismoreau F, Hilscher MM, Yokota C, Qian X, Nilsson M, Bronner ME, Croci L, Hsiao WY, Guertin DA, Brunet JF, Consalez GG, Ernfors P, Fried K, Kharchenko PV, Adameyko I. 2019. Spatiotemporal structure of cell fate decisions in murine neural crest. Science 364, 971.

Stemple DL, Anderson DJ. 1992. Isolation of a stem cell for neurons and glia from the mammalian neural crest. Cell 71:973-985.

Taneyhill LA, Coles EG, Bronner-Fraser M. 2007. Snail2 directly represses cadherin6B during epithelial-to-mesenchymal transitions of the neural crest. Development 134:1481-1490. 
Thomas AJ, Erickson CA. 2009. FOXD3 regulates the lineage switch between neural crest-derived glial cells and pigment cells by repressing MITF through a non-canonical mechanism. Development 136:1849-1858.

Thomas LA, Yamada KM. 1992. Contact stimulation of cell migration. J. Cell Sci. 103:1211-1214.

Thomas S, Thomas M, Wincker P, Babarit C, Xu P, Speer MC, Munnich A, Lyonnet S, Vekemans M, Etchevers HC. 2008. Human neural crest cells display molecular and phenotypic hallmarks of stem cells. Hum Mol Genet 17:3411-3425.

Trainor P. 2013. Neural Crest Cells: Evolution, Development and Disease. Elsevier. 488 p.

Trichet L, Le Digabel J, Hawkins RJ, Vedula SR, Gupta M, Ribrault C, Hersen P, Voituriez R, Ladoux B. 2012. Evidence of a large-scale mechanosensing mechanism for cellular adaptation to substrate stiffness. Proc Natl Acad Sci USA 109:6933-6938.

Tucker GC, Aoyama H, Lipinski M, Tursz T, Thiery JP. 1984. Identical reactivity of monoclonal antibodies HNK-1 and NC-1: Conservation in vertebrates on cells derived from the neural primordium and on some leukocytes. Cell Diff. 14:223-230.

Tucker GC, Delarue M, Zada S, Boucaut J-C, Thiery JP. 1988. Expression of HNK-1/NC-1 epitope in early vertebrate neurogenesis. Cell Tiss. Res. 251:457-465.

Uchikawa M, Ishida Y, Takemoto T, Kamachi Y, Kondoh H. 2003. Functional analysis of chicken Sox2 enhancers highlights an array of diverse regulatory elements that are conserved in mammals. Dev Cell 4:509-519.

Vedula SR, Leong MC, Lai TL, Hersen P, Kabla AJ, Lim CT, Ladoux B. 2012. Emerging modes of collective cell migration induced by geometrical constraints. Proc Natl Acad Sci USA 109:1297412979.

Vincent M, Thiery JP. 1984. A cell surface marker for neural crest and placodal cells: Further evolution in peripheral and central nervous system. Dev. Biol 103:468-481.

Wang HU, Anderson DJ. 1997. Eph family transmembrane ligands can mediate repulsive guidance of trunk neural crest migration and motor axon outgrowth. Neuron 18:383-396.

Weider M, Wegner M. 2017. SoxE factors: Transcriptional regulators of neural differentiation and nervous system development. Semin Cell Dev Biol 63:35-42.

Williams RM, Candido-Ferreira I, Repapi E, Gavriouchkina D, Senanayake U, Ling ITC, Telenius J, Taylor S, Hughes J, Sauka-Spengler T. 2019. Reconstruction of the Global Neural Crest Gene Regulatory Network In Vivo. Dev Cell 51:255-276 e257.

Ziller C, Dupin E, Brazeau P, Paulin D, Le Douarin NM. 1983. Early segregation of a neuronal precursor cell line in the neural crest as revealed by culture in a chemically defined medium. Cell 32:627-638.

\section{FIGURE LEGENDS}

Fig. 1: Specific glassware (A) and microsurgery tools (B) used for neural crest cell culture. A. A widened bowl to collect yolks from the eggs (left) and a glass Petri dish containing silicone rubber to collect and dissect the embryos. B. Microsurgery tools used throughout the protocol: 1. curved scissors with sharp ends; 2. a Moria perforated spoon; 3. straight forceps with very thin tips (Dumont no. 4); 4. straight scissors with sharp ends; 5 . a pair of minutien pins mounted on pin holders with screw for microdissections; 6. a scalpel with disposable no. 15 blade.

Fig. 2: Collecting the embryo from the egg. A. Collecting the yolk out of the shell. Panels 1-8 depict the method for opening the egg with curved-end scissors and transferring the yolk into a bowl half-filled with PBS. B. Separating the embryo from the yolk. Panel 1 show a detailed view of an intact embryo surrounded by its yolk sac (ys) prior to extirpation from the yolk. Arrows point to the blood vessel network and blood islands in the yolk sac. Panels 2-8 depict the different steps of the method for trimming the embryo and its surrounding tissues with forceps and curved-end scissors and grabbing with a perforated spoon. The position of the embryo is indicated by the asterisk. 
Fig. 3: Isolating the trunk segments. A. Overview of an embryo at stage 14-15 with 25 somite pairs which has been removed from the yolk and pinned down onto silicone in a glass dish filled with PBS. The vitelline membrane is stretched out with 4 insect pins placed away from the embryo out of the vascularized area of the yolk sac (ys). The embryo proper is surrounded by a yellow line. B. Panel 1 is a detailed view of the embryo shown in A before dissecting the trunk segment out. The embryo is oriented with its anterior (ant.) side at the top and the posterior (post.) one at the bottom. Note that while the head of the embryo is turned such that it presents its right side to the observer (the heart can be seen on the right), the trunk remains straight and is oriented with its dorsal side up. The arrows point to the large extraembryonic blood vessels entering the embryo at the level of the 20 th and $21^{\text {st }}$ somites indicated by yellow dots. Panels 24 show the different steps of trimming the trunk segment situated between the 5 th somite pair above the last formed one and the first nascent pair in the anterior part of the unsegmented mesoderm, noted s5 and s-1 respectively. The neural tube (nt) is the solid cord situated in the midline and flanked by the two rows of ball-shaped somites. Bars in B1-B4: $500 \mu \mathrm{m}$.

Fig. 4: Dissecting and transferring the neural tubes to culture dish. A. Panels 1-4 show the main steps of neural tube dissection with dissection pins: removal of the overlying ectoderm, separation of the left row of somites (s) from the neural tube (nt), separation of the right row, and complete isolation of the neural tube. Panels 1'-4' are schematic representations of the trunk segment shown in panels 1-4 to illustrate the different tissues for an easier orientation: ectoderm in yellow, neural tube in blue, somites and lateral mesoderm in dark and light green, and endoderm in red. The arrows indicate the movements of the dissection pins. Bar $=500 \mu \mathrm{m}$. B. Panel 1 shows the dissected neural tube (nt) free of neighboring tissues except the notochord (n) attached to its ventral side. Bar $=100 \mu \mathrm{m}$. Panel 2 shows a culture well made from flexible 96-well Falcon plates deposited in a 35-mm dish and filled with DMEM before transferring the dissected neural tube. Panels 3-4 show the neural tube transfer into the culture well with a 200$\mu \mathrm{l}$ pipette tip and its positioning and orientation into the well. Bars in $2-4=1 \mathrm{~mm}$.

Fig. 5: Morphological and population features of neural crest cells in 24 hour-cultures. A. B. Comprehensive phase contrast views over time of a neural tube initially deposited on the dish either dorsally (A) or laterally (B) and cultured in DMEM medium supplemented with $1 \%$ serum. The midline of the neural tube in A appears as a darker zone along its entire length. Delaminating neural crest cells initiating spreading onto the substratum are indicated by arrows. Note the presence of numerous vesicles released by the neural tube on the dish during the early steps of the culture (asterisks). These vesicles are in no way contaminants or cell debris due to massive cell death. They are taken up by migrating neural crest cells and disappear with time. C. Detailed phase contrast views of a neural tube explant showing the morphology of migrating neural crest cells. Individual neural crest cell contours can be easily distinguished even in the middle of the outgowth where cell density is high. D. Phase contrast view of a neural crest outgrowth in which the neural tube explant has been removed manually after 24 hours in culture, leaving its print (double asterisk) surrounded by intact neural crest cells. Bars $=100$ $\mu \mathrm{m}$.

Fig. 6: Phenotypic characterization of neural crest cell cultures after 24 hours with cell lineage markers. A. Immunofluorescence labelings of neural tube explants with antibodies to Sox-10, Snail-2, Sox-2 and HNK-1 revealed by secondary antibodies conjugated to Alexa-488 (green) or Cy-3 (red). Cells nuclei are visualized with Hoechst staining (blue). B. In situ hybridizations (blue colors) for Snail-2, Sox-10, Sox-2, Foxd-3, cadherin-6B, and N-cadherin, combined with immunoperoxidase stainings for HNK-1 (brown color). After 24 hours in culture, Sox-10 and HNK-1 show widespread expression in almost the entire population of undifferentiated, 
migrating neural crest cells, while Snail-2 and cadherin-6B identify only a subset of neural crest cells situated along the neural tube explant and corresponding to premigratory and early delaminating neural crest cells (arrows in A1, A2, B1 and B5). Note that Snail-2- and cadherin6B-positive cells are essentially discernable in the posterior half of the neural tube and not in its anterior part, reflecting the temporal progression of neural crest cell emigration along the anteroposterior axis. Finally, Sox-2 and N-cadherin are restricted to neural epithelial cells in the neural tube. Bars $=100 \mu \mathrm{m}$.

Fig. 7: Tracking avian trunk neural crest cell migration in culture. A. Image of a neural tube explant analyzed by videomicroscopy showing a view of the neural tube taken after three hours of culture, at the time of the beginning of recording, and the tracks and positions of several individual cells over time. Time lapse videomicroscopy was performed with a 10x objective and images were recorded every 5 minutes during 16 hours. B. C. Graphs showing the mean values of neural crest cell speed of locomotion in $\mu \mathrm{m} /$ hour and the directionality of movement every hour, respectively.

Fig. 8: Phenotypic characterisation of neural crest cell cultures after several days in culture with cell lineage markers. A. Phase contrast overview of a 48-hour neural tube explant, showing, on the left, the dense network of neurites (arrows) emerging out of the ventral side of the neural tube and, on the right, the presence of cells with distinct morphologies and shapes among the neural crest cell population. B. Detailed views of the main cell types derived from the neural crest outgrowth after 3 or 5 days in culture: Panel 1, large, well spread myofibroblasts; Panel 2, neurons with long neurites sitting on top of neural crest cells; and Panel 3, little, aster-shaped melanoblasts. Note that these cells are often assembled as separate colonies. C. Immunofluorescence labelings of neural crest-derived cell populations after 3 days in culture with antibodies to Sox-10, HNK-1, alpha-SMA, betaIII-tubulin (Tuj-1), and Mitf revealed by secondary antibodies conjugated to Alexa-488 (green), Cy-3 (red) and Cy-5 (purple in C1-C3 and yellow in C4). Nuclei are visualized with Hoechst staining (blue). Panel 1 shows a group of myofibroblasts characterized by a dense meshwork of alpha-SMA in their cytoplasm. Most of them do not express Sox-10 in their nuclei and HNK-1 on their surface, but a few cells corresponding possibly to myofibroblasts having not yet completed their differentiation process express all three markers together (arrows). Beside myofibroblasts, a few large cells with an astrocyte-like shape and expressing both HNK1 and Sox-10 represent early-differentiating glial cells (arrowheads). Panel 2 shows neurons expressing betaIII-tubulin but no Sox-10. Panel 3 shows a large group of melanoblasts expressing MITF in their nuclei but no HNK-1. As for myofibroblasts, a few melanoblasts can be seen coexpressing Mitf and HNK-1 (arrows), likely corresponding to early melanoblasts. Panel 4 shows persistent Sox-10 positive, HNK-1 positive undifferentiated neural crest cell progenitors in the outgrowth. Bars in A, B and C $=100 \mu \mathrm{m}$. 
Table I: Markers for undifferentiated neural crest cells and their derivatives used in immunostaining (IS) and in situ hybridization (ISH) techniques.

(1) Although there are many antibodies to Sox-10 available from many sources, not all of them can be applied for immunolabeling of neural crest cells in avians.

(2) The original HNK-1 hybridoma cell line producing an IgM is available from the ATCC. However, several mouse mAbs, clones $1 \mathrm{C} 10,3 \mathrm{H} 5$, zn-12, recognizing the HNK-1 epitope can now be purchased from the Developmental Studies Hybridoma Bank (DSHB).

(3) The mAb to cadherin-6B available from DSHB (clone CCD6B) has been successfully used by several groups (Taneyhill et al., 2007; Park and Gumbiner, 2012). However, for unknown reasons, none of the different batches of this antibody that we tested gave significant reliable staining in our hands.

\begin{tabular}{|l|l|l|l|}
\hline Marker & Cell type specificity & $\begin{array}{l}\text { Detection } \\
\text { method }\end{array}$ & Antibody source/Reference for ISH \\
\hline Sox-10 & $\begin{array}{l}\text { Undifferentiated, migrating } \\
\text { neural crest cells } \\
\text { Schwann cells, Melanoblasts }\end{array}$ & IS & $\begin{array}{l}\text { Mouse mAb clone A2 (Santa Cruz, } \\
\text { cat. no. sc-365692) (1) } \\
\text { (Cheung et al., 2005) }\end{array}$ \\
\hline Sox-2 & $\begin{array}{l}\text { Neural epithelial cells } \\
\text { Neurons of the PNS }\end{array}$ & IS & $\begin{array}{l}\text { Rabbit polyclonal Ab (Abcam, cat. no. } \\
\text { 97959) } \\
\text { (Uchikawa et al., 2003) }\end{array}$ \\
\hline Snail-2 & $\begin{array}{l}\text { Premigratory and early migrating } \\
\text { neural crest cells }\end{array}$ & IS & $\begin{array}{l}\text { Rabbit mAb clone C19G7 (Cell Signaling, } \\
\text { cat. no. 9585) } \\
\text { (Nieto et al., 1994) }\end{array}$ \\
\hline HNK-1 & $\begin{array}{l}\text { Migrating neural crest cells } \\
\text { Neurons }\end{array}$ & IS & $\begin{array}{l}\text { Mouse mAb clones 1C10, 3H5, zn-12 } \\
\text { (Developmental Studies Hybridoma } \\
\text { Bank, RRID: AB_10570406, AB_2314644, } \\
\text { AB_531908) (2) }\end{array}$ \\
\hline Foxd-3 & $\begin{array}{l}\text { Migrating neural crest cells } \\
\text { not melanoblasts }\end{array}$ & ISH & (Thomas and Erickson, 2009) \\
\hline
\end{tabular}




\begin{tabular}{|l|l|l|l|}
\hline Cadherin-6B & Premigratory neural crest cells & ISH & $\begin{array}{l}\text { (Nakagawa and Takeichi, 1995; Dady and } \\
\text { Duband, 2017) (3) }\end{array}$ \\
\hline N-cadherin & Neural epithelial cells & IS & $\begin{array}{l}\text { Mouse mAb clone GC-4 (Sigma, cat. no. } \\
\text { C3865) } \\
\text { (Dady and Duband, 2017) }\end{array}$ \\
\hline$\alpha$-SMA & Myofibroblasts & ISH & $\begin{array}{l}\text { Mouse mAb clone 1A4 (Sigma, cat. no. } \\
\text { A2547) }\end{array}$ \\
\hline$\beta$ III-tubulin & Neurons & IS & $\begin{array}{l}\text { Mouse mAb clone TUJ-1 (R\&D Systems, } \\
\text { cat. no. MAB1195) }\end{array}$ \\
\hline MITF & Melanoblasts & IS & $\begin{array}{l}\text { Mouse mAb clone C5 (Abcam, cat. no. } \\
\text { ab12039) }\end{array}$ \\
\hline BLBP & Glia & IS & $\begin{array}{l}\text { Rabbit polyclonal Ab (Millipore, } \\
\text { cat. no. ABN14) }\end{array}$ \\
\hline GFAP & Glia & IS & $\begin{array}{l}\text { Chicken polyclonal Ab (Abcam, cat. no. } \\
\text { ab4674) }\end{array}$ \\
\hline
\end{tabular}






Figure 1: Duband et al. 


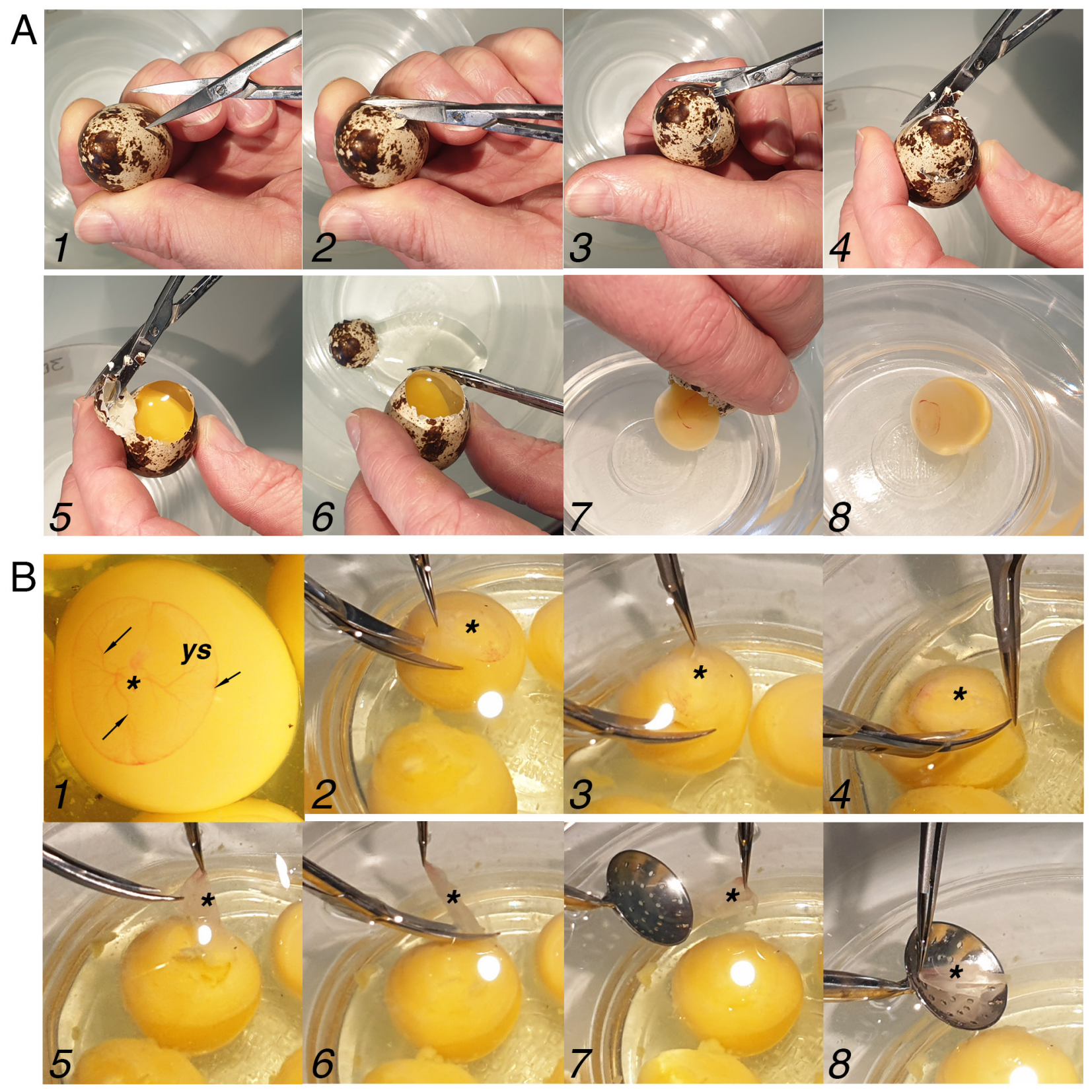

Figure 2: Duband et al. 


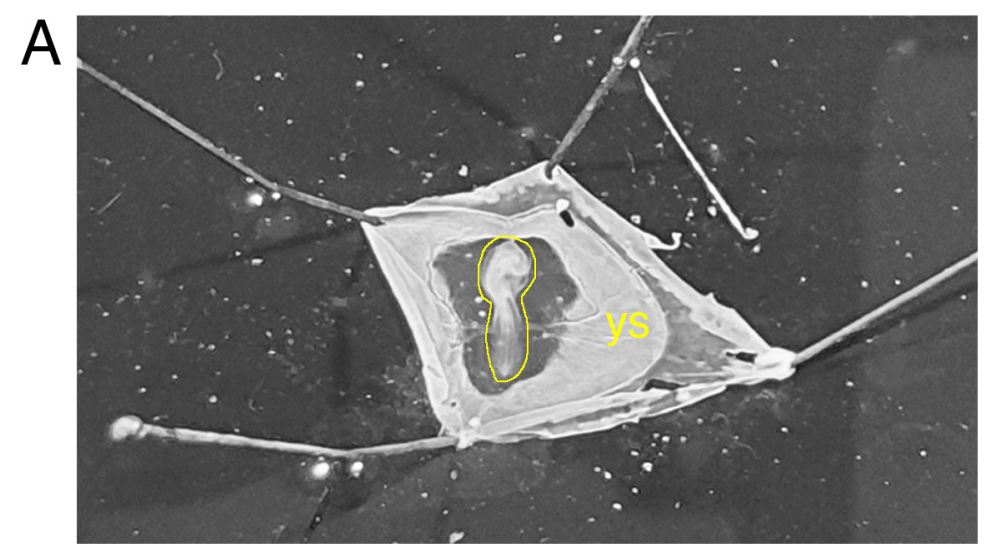

\section{B}
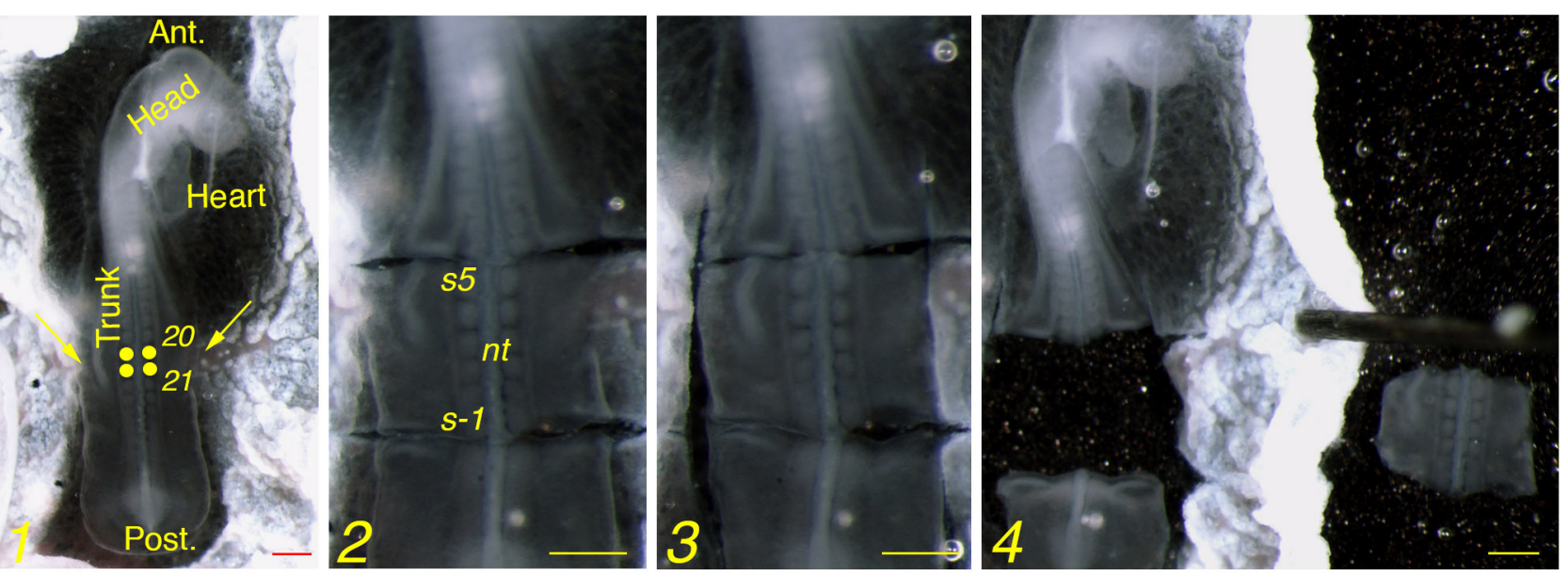

Figure 3: Duband et al. 

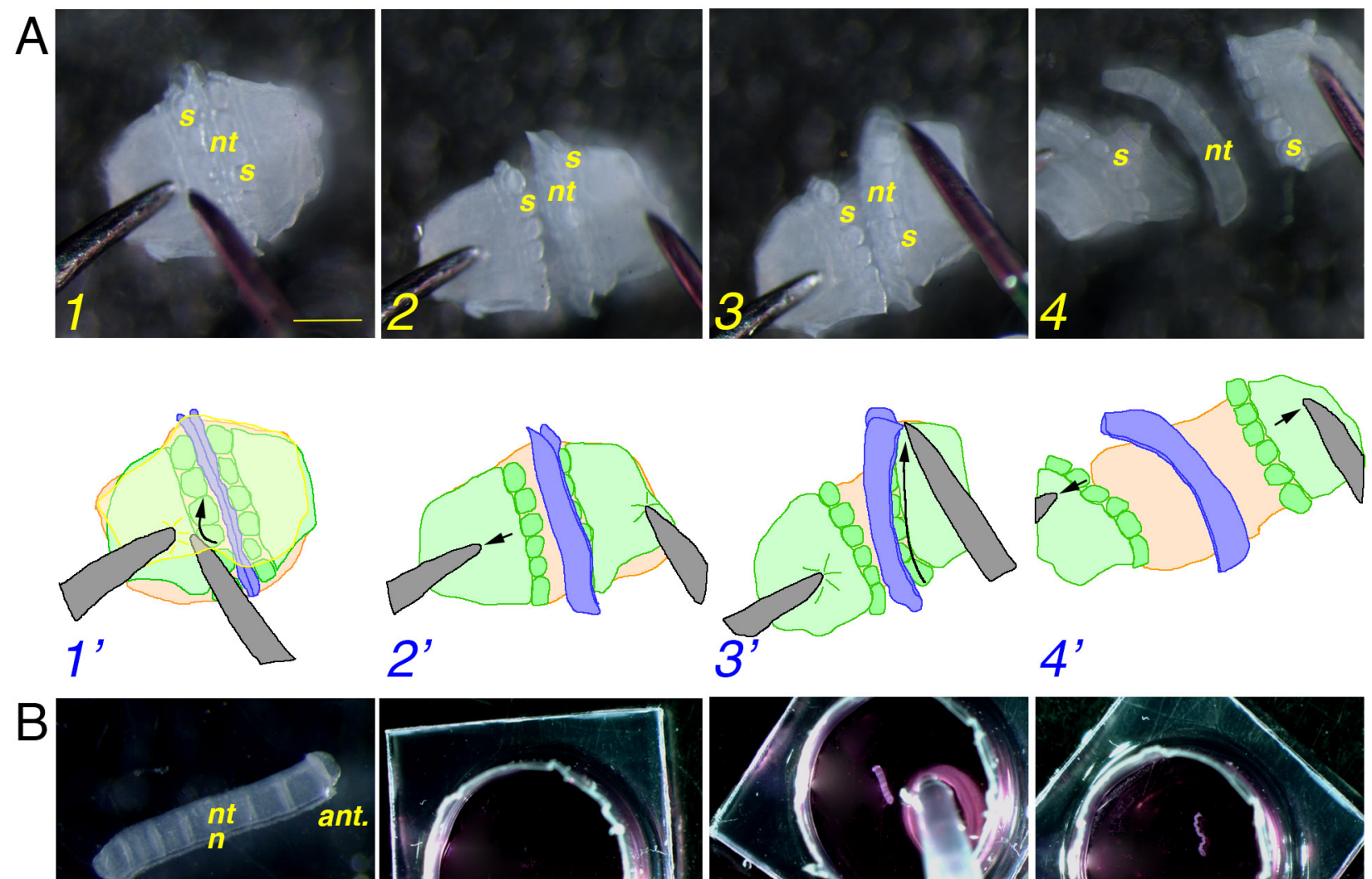

post.

1
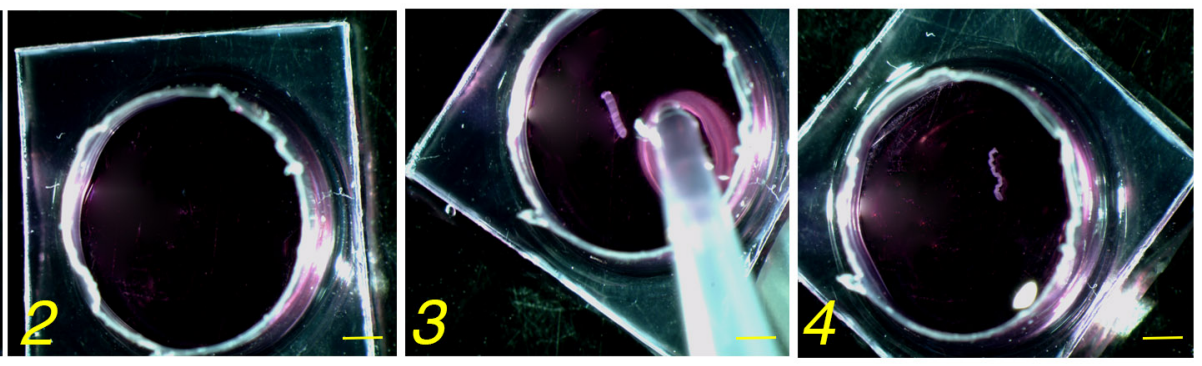

Figure 4: Duband et al. 

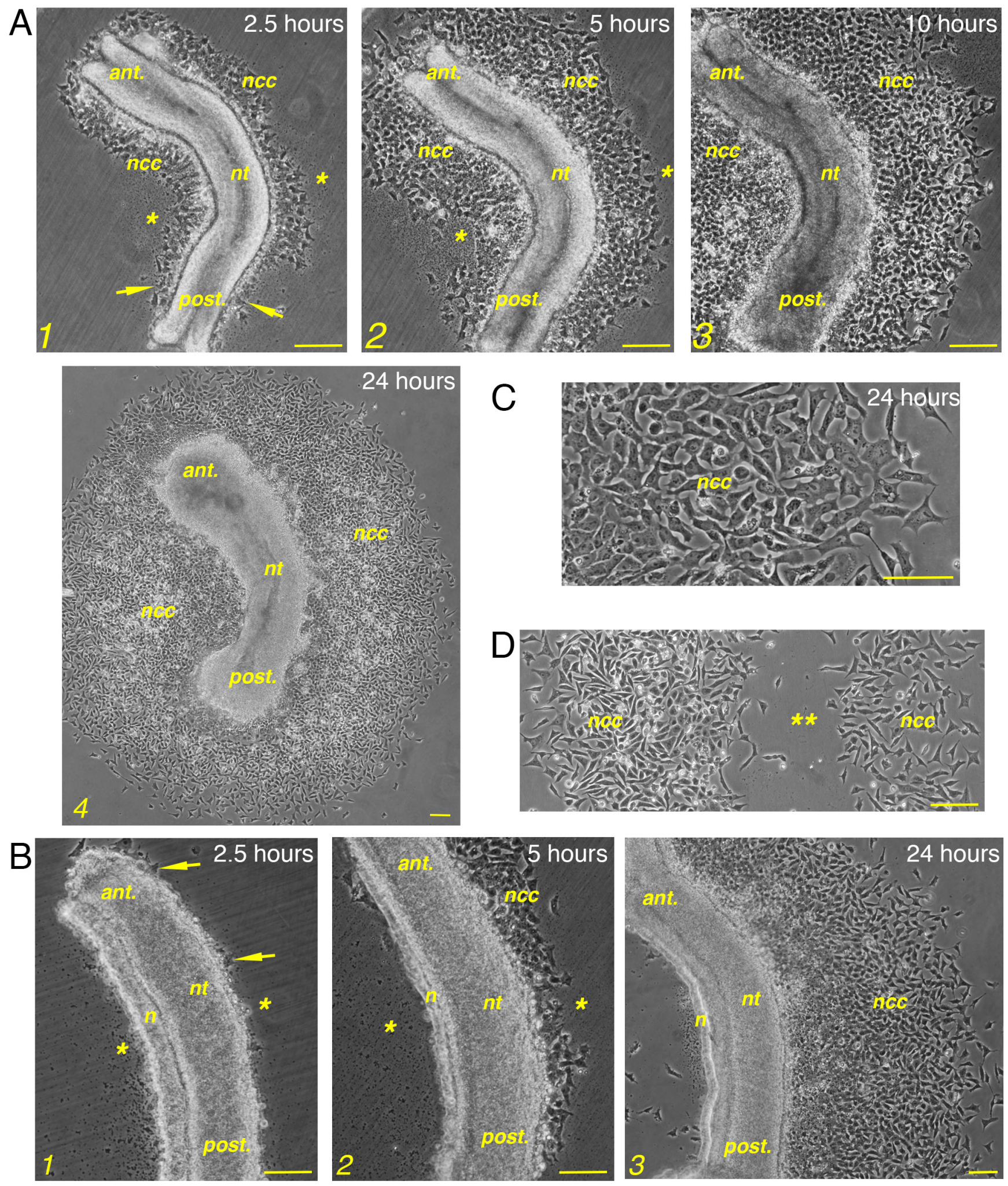

Figure 5: Duband et al. 

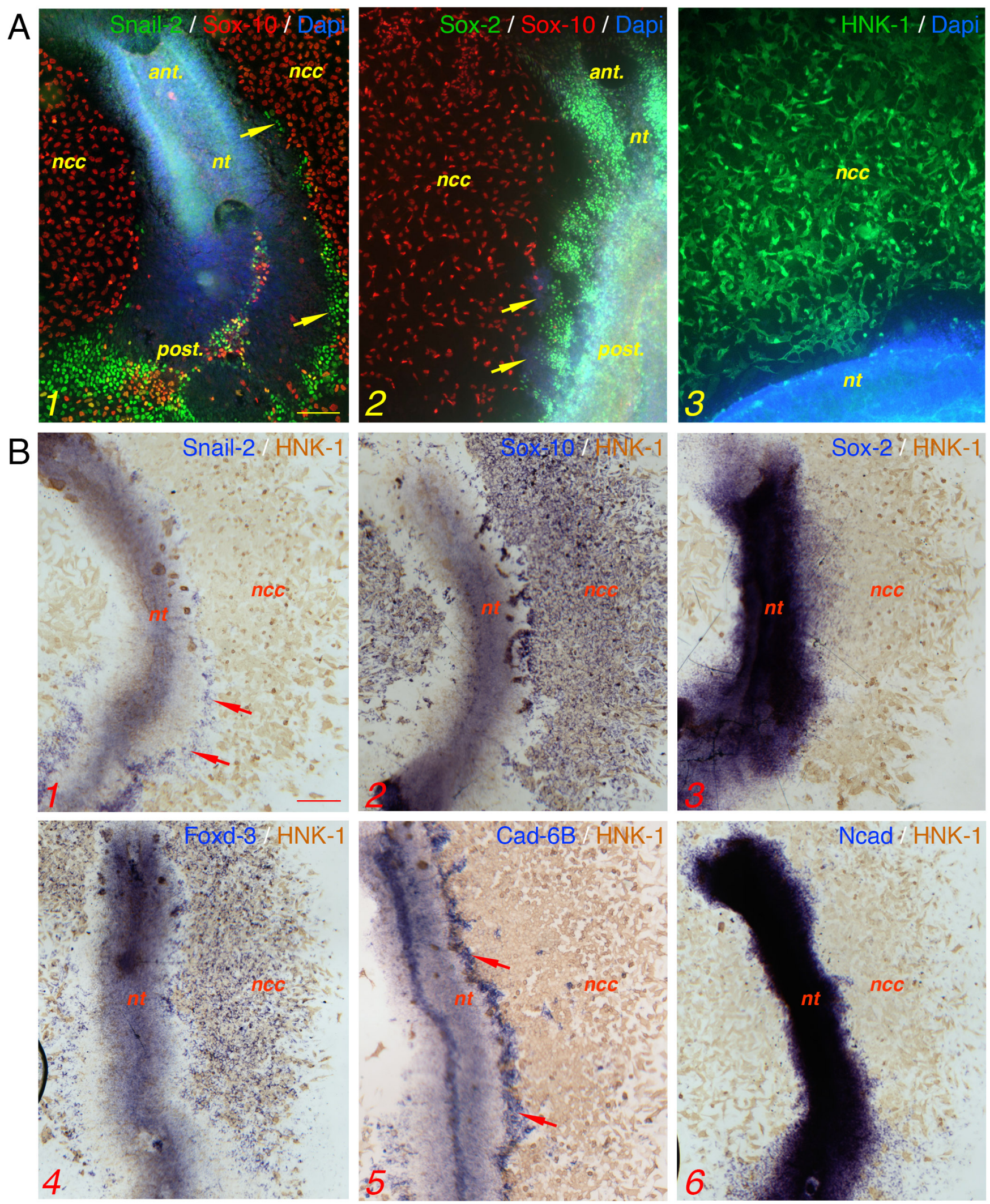

Figure 6: Duband et al. 

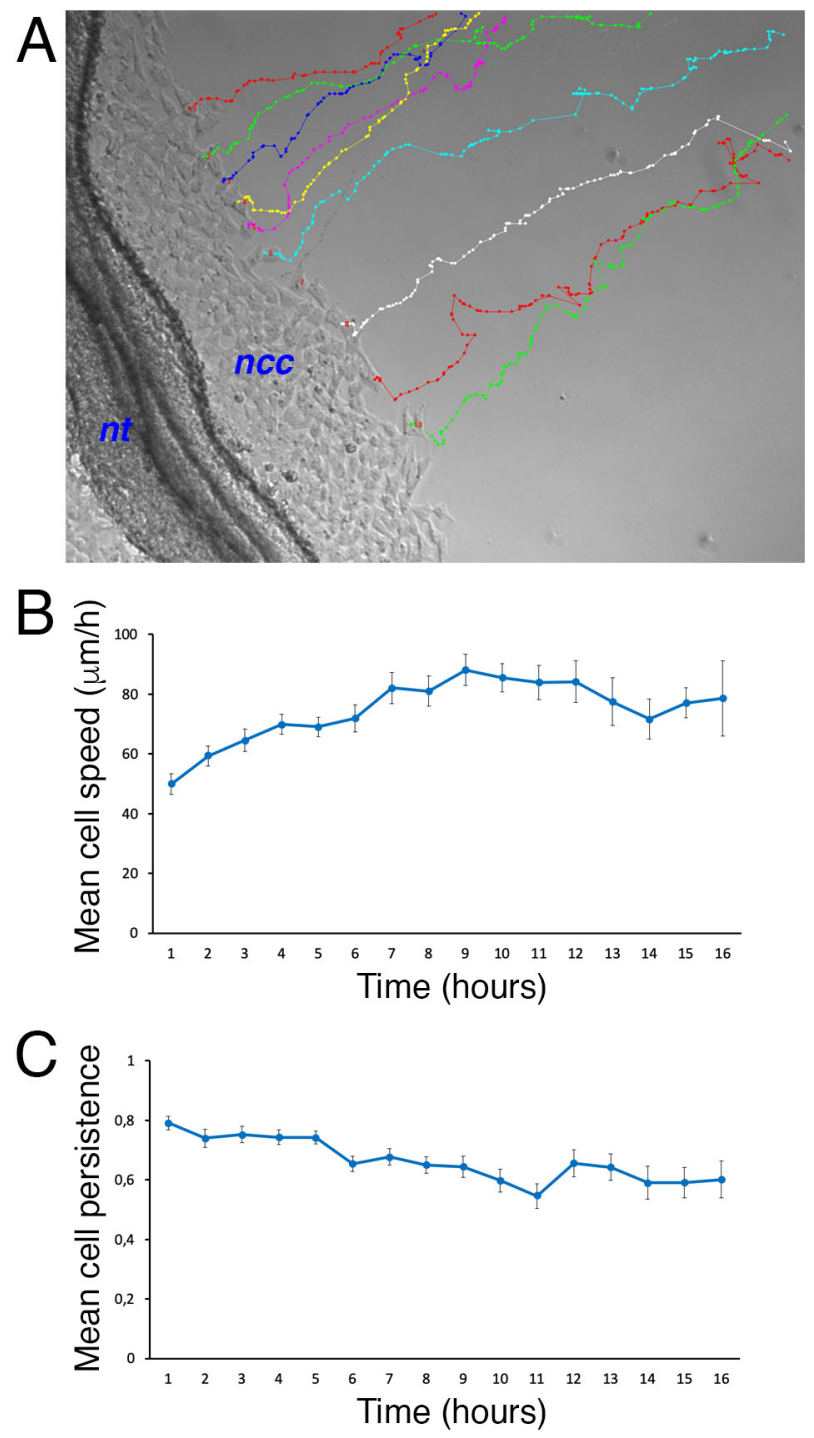

Figure 7: Duband et al. 


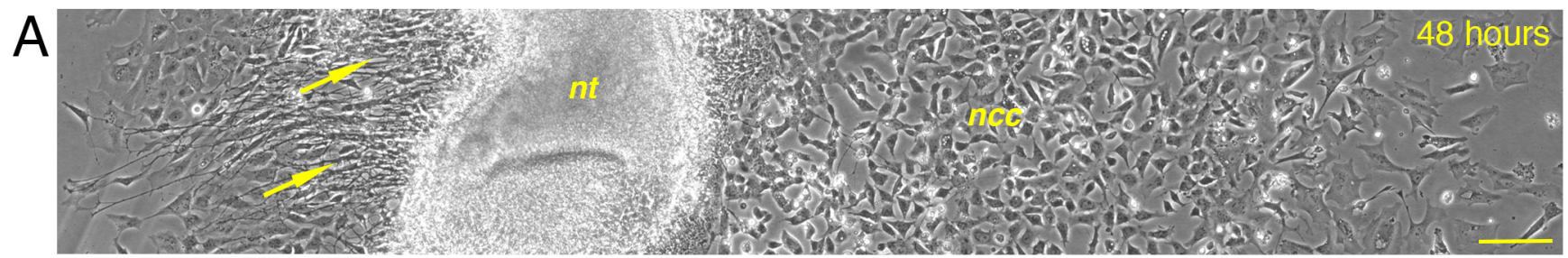

B

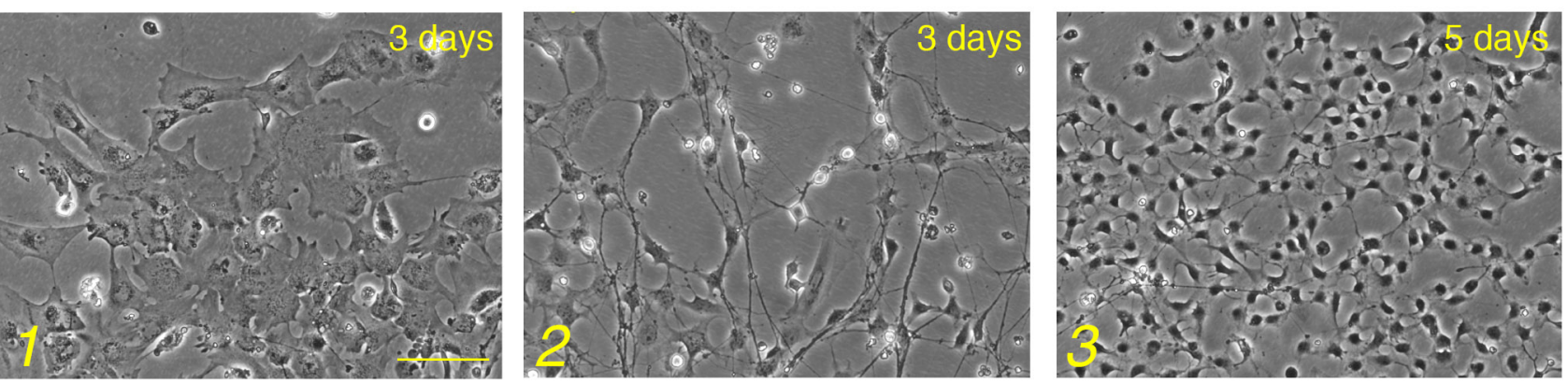

C
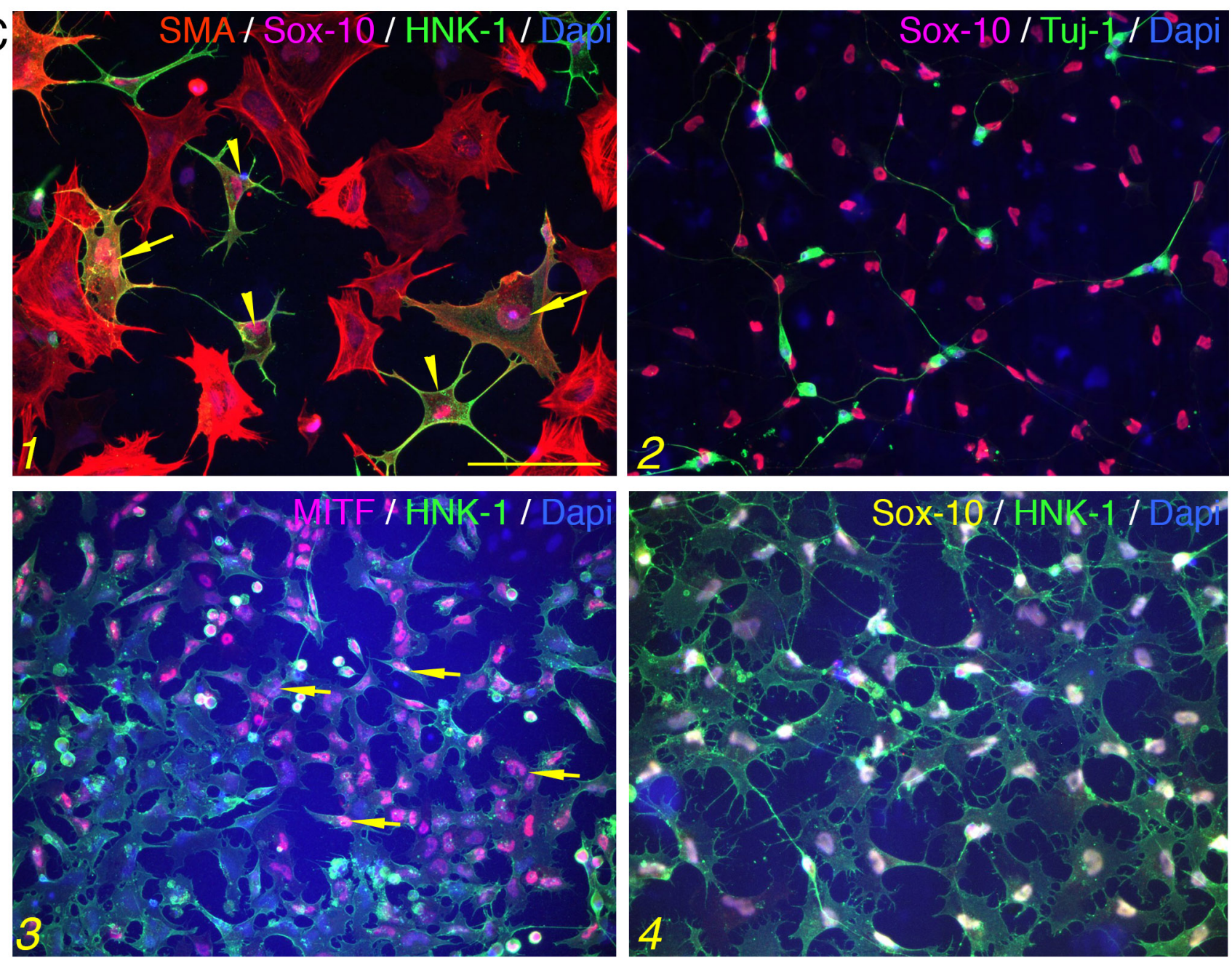

Figure 8: Duband et al. 